\title{
National Register Testing at 41HM46, Hamilton County, Texas: CR 294 Bridge Replacement at the Leon River
}

John E. Dockall

Cory J. Broehm

Karl W. Kibler

Cross Timbers Geoarcheological Services

Follow this and additional works at: https://scholarworks.sfasu.edu/ita

Part of the American Material Culture Commons, Archaeological Anthropology Commons, Environmental Studies Commons, Other American Studies Commons, Other Arts and Humanities Commons, Other History of Art, Architecture, and Archaeology Commons, and the United States History Commons

Tell us how this article helped you.

This Article is brought to you for free and open access by the Center for Regional Heritage Research at SFA ScholarWorks. It has been accepted for inclusion in Index of Texas Archaeology: Open Access Gray Literature from the Lone Star State by an authorized editor of SFA ScholarWorks. For more information, please contact cdsscholarworks@sfasu.edu. 


\section{National Register Testing at 41HM46, Hamilton County, Texas: CR 294 Bridge Replacement at the Leon River}

\section{Licensing Statement}

This is a work for hire produced for the Texas Department of Transportation (TxDOT), which owns all rights, title, and interest in and to all data and other information developed for this project under its contract with the report producer. The report may be cited and brief passages from this publication may be reproduced without permission provided that credit is given to TXDOT and the firm that produced it. Permission to reprint an entire chapter, section, figures or tables must be obtained in advance from the Supervisor of the Archeological Studies Branch, Environmental Affairs Division, Texas Department of Transportation, 125 East 11th Street, Austin, Texas, 78701 


\title{
NATIONAL REGISTER TESTING AT 41HM46, HAMILTON COUNTY, TEXAS: CR 294 BRIDGE REPLACEMENT AT THE LEON RIVER
}

\author{
by \\ John E. Dockall \\ Cory J. Broehm \\ and
}

Karl W. Kibler

Principal Investigator: Karl W. Kibler

TECHNICAL REPORTS, NUMBER 86

Prewitt and Associates, Inc.

Cultural Resources Services

Austin, Texas

PAI No. 211011

\author{
ARCHEOLOGICAL STUDIES PROGRAM, REPORT NO. 141 \\ Texas Department of Transportation \\ Environmental Affairs Division \\ Austin, Texas
}

December 2011

TEXAS ANTIQUITIES PERMIT NO. 3211 


\section{NATIONAL REGISTER TESTING AT 41HM46, HAMILTON COUNTY, TEXAS: CR 294 BRIDGE REPLACEMENT AT THE LEON RIVER}

COPYRIGHT @ 2011

Texas Department of Transportation (TxDOT) and Prewitt and Associates, Inc. (PAI)

This is a work for hire produced by the Texas Department of Transportation (TxDOT), which owns all rights, title, and interest in and to all data and other information developed for this project under Contract Nos. 571XXSA001 and 573XXSA001. Brief passages from this publication may be reproduced without permission provided that credit is given to TxDOT and Prewitt and Associates, Inc. Permission to reprint an entire chapter, section, figures, or tables must be obtained in advance from the Supervisor of the Archeological Studies Program,

Environmental Affairs Division, Texas Department of Transportation, 125 East 11th Street, Austin, Texas, 78701. Copies of this publication have been deposited with the Texas State Library in compliance with the State Depository Requirement.

jointly published by the

Texas Department of Transportation

Environmental Affairs Division

Archeological Studies Program

Scott Pletka, Ph.D., Supervisor, Archeological Studies Program

Archeological Studies Program, Report No. 141

Al McGraw, Series Editor

and

Prewitt and Associates, Inc.

Cultural Resources Services

Austin, Texas

PAI Project Nos. 203032, 210044 and 211011

Technical Reports, Number 86

Printed by Alphagraphics Printing in Austin, Texas 


\section{TABLE OF CONTENTS}

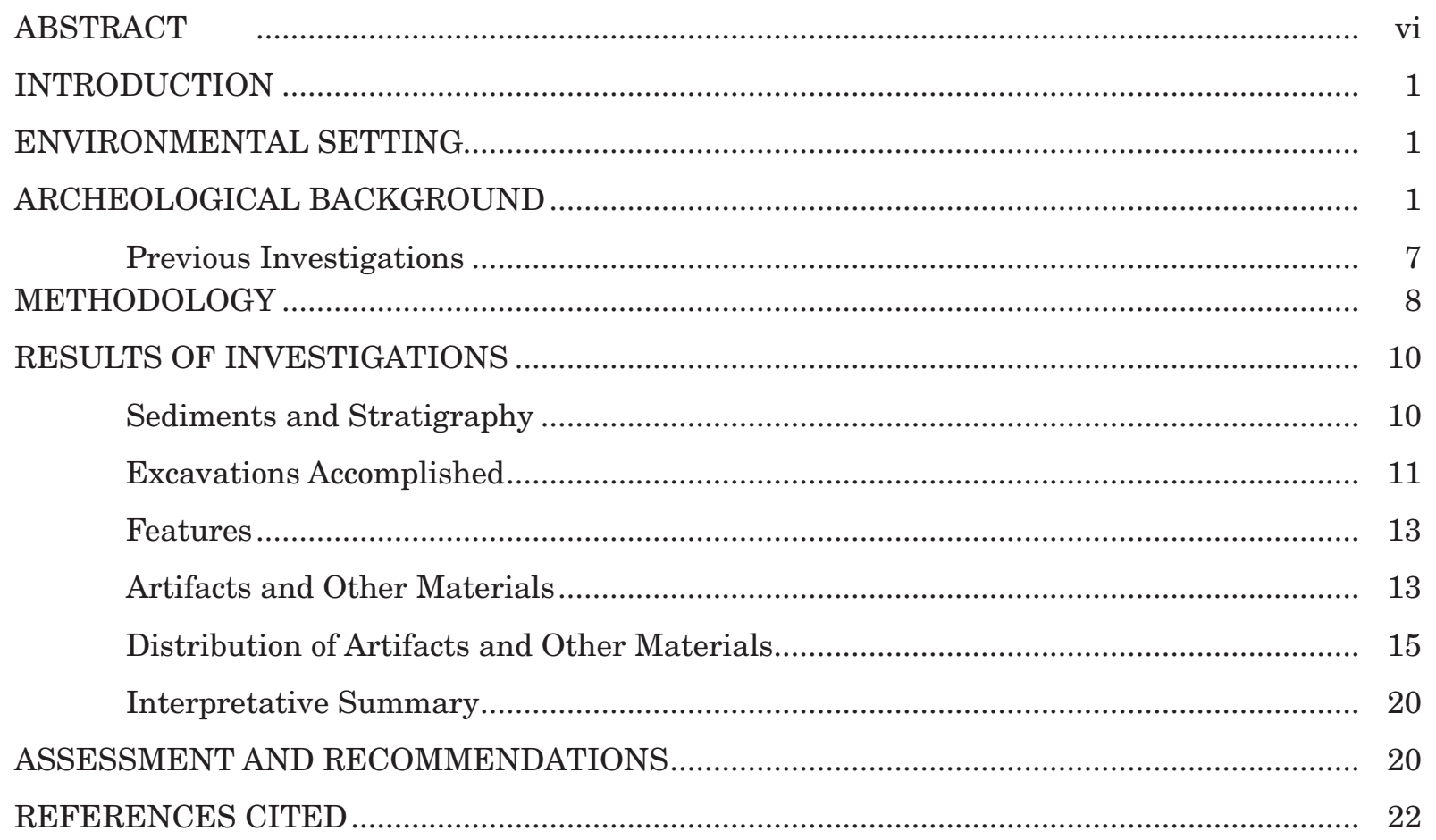




\section{LIST OF FIGURES}

1. Project location map showing 41HM46 .......................................................................... 2

2. Site 41HM46 looking southwest ....................................................................................

3. Site map of 41HM46 showing the locations of backhoe trenches, shovel tests,

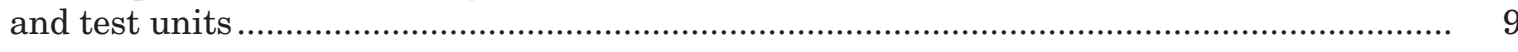

4. Schematic of the project area's geomorphology and stratigraphy ....................................... 11

5. Overview of Backhoe Trench 3 with the buried soil exposed across the bottom

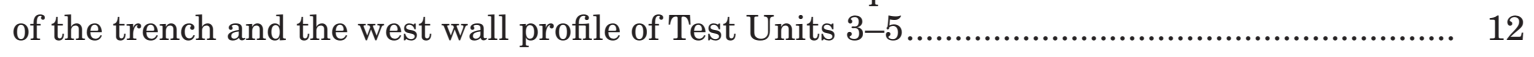

6. Lithic artifacts recovered from excavated contexts at 41HM46 ......................................... 14

7. Graphs showing vertical distribution of cultural materials.................................................. 19 


\section{LIST OF TABLES}

1. Cultural materials recovered from 41HM46 by test unit.................................................. 14

2. Summary of cultural materials from 41HM46 by test unit and level ............................... 16 


\begin{abstract}
Prewitt and Associates, Inc., conducted test excavations at site 41HM46 in Hamilton County, Texas, to determine its eligibility for listing in the National Register of Historic Places. The work was performed in September 2003 in conjunction with a proposed bridge replacement on County Road 294 over the Leon River.

The excavations consisted of three backhoe trenches, eight shovel tests, and seven hand-dug test units totaling $7 \mathrm{~m}^{3}$. Excavations yielded a small assemblage of chipped stone artifacts (tools, cores, and unmodified debitage), two features, and other cultural materials that appear to be associated with occupations ranging from the Late Archaic to possibly the Late Prehistoric. Although most of the artifacts and other cultural materials were recovered from an undisturbed cumulic soil, there was no clear vertical separation of deposits or discrete components. The low artifact frequency, lack of well-defined features, and scarcity of potential temporal indicators such as diagnostic tools or charcoal for radiocarbon dating make the site unlikely to yield important information. Based on these factors, it is recommended that 41HM46 be judged ineligible for listing in the National Register of Historic Places.
\end{abstract}

\title{
CURATION
}

All artifacts, records, and cultural materials generated by this project are curated at the Center for Archaeological Research at the University of Texas at San Antonio. 


\section{INTRODUCTION}

This report presents the results of National Register test excavations at 41HM46. The work was conducted by Prewitt and Associates, Inc. for the Texas Department of Transportation (TxDOT), Environmental Affairs Division, under Contract No. 573XXSA001, Work Authorization No. 57309SA001, and Antiquities Permit No. 3211 issued by the Texas Historical Commission. The test excavations were completed to assist TxDOT in complying with Section 106 of the National Historic Preservation Act and the Antiquities Code of Texas. At least part of the site is located within existing and new right of way for the proposed replacement of the CR 294 bridge over the Leon River. This project will replace the existing ca. 1890 bridge with a new structure located 55-61 m west (upstream) of the existing bridge, straightening out an undesirable curve on CR 294. The new bridge will be $55 \mathrm{~m}$ long and $7 \mathrm{~m}$ wide. The approaches will be reworked to match the new structure and will require approximately 1.72 acres of new right of way.

Site 41HM46 is in Hamilton County $12 \mathrm{~km}$ northwest of the city of Hamilton (Figure 1). The site was recorded in June 2003 during a survey for the proposed bridge project (Kibler 2003). Cultural materials associated with 41HM46 were observed within a buried soil that was exposed in one of two backhoe trenches excavated during the survey. The cumulic nature of this soil was considered to have the potential to contain discrete artifact and feature assemblages for study. Based on the contextual integrity of the artifacts and other cultural materials at the site, it was believed that 41HM46 had the potential to contribute important information. It was therefore recommended that the site be tested to assess its eligibility for the National Register. Test excavations were conducted September 2003.

\section{ENVIRONMENTAL SETTING}

The project area lies within the Western Cross Timbers, a gently rolling wooded landscape of deciduous oaks formed on the outcrop of the basal Trinity Group sands (Twin Mountain and Antlers Formations) along the western margins of the Grand Prairie (Hayward et al. 1996:1-9). The plant community of the West- ern Cross Timbers is characterized by post, blackjack, and Texas red oaks, with pecans, bur oaks, cottonwoods, elms, hackberries, and sycamores predominating in the floodplains of watercourses. Fauna of the region are characteristic of the Texan biotic province, where 49 species of mammals, 2 species of turtles, 16 species of lizards, 39 species of snakes, and 23 species of amphibians have been documented (Blair 1950:100-102). Vegetation observed in the project area consists of pecan and sycamore trees with an understory of various grasses, greenbrier, and vines (Figure 2).

The Leon River is part of the Brazos River drainage system. Rocky Creek drains into the Leon River ca. $200 \mathrm{~m}$ upstream from the project area. An old channel of the Leon River is mapped ca. $150 \mathrm{~m}$ east of the project area and flows eastward before joining with the present channel of the Leon River ca. $4.5 \mathrm{~km}$ downstream.

Holocene alluvium from the Leon River is mapped within the project area (Bureau of Economic Geology 1976). The alluvium, in the form of terraces and a floodplain, is flanked by the lower Cretaceous Glen Rose and Twin Mountains formations. The project area is situated on the $\mathrm{T}_{1}$ terrace on the south side the Leon River. The terrace stands ca. $5 \mathrm{~m}$ above the channel, and soils of the Frio series are mapped on the terrace surface (Hamilton-Coryell SWCD n.d.). These soils are described as dark grayish brown to very dark grayish brown silty clays, generally at least $1.52 \mathrm{~m}$ thick, and found on bottomlands with $0-1$ percent slopes. They form in calcareous silty clay loam and silty clay alluvium (Moore et al. 1977:54).

\section{ARCHEOLOGICAL BACKGROUND}

The Leon River is part of the middle Brazos River drainage system, which is in the central Texas archeological region (e.g., Prewitt 1981, Suhm 1960). This archeological region is recognized based on decades of investigations at various stratified sites throughout areas of the Edwards Plateau, its highly dissected eastern and southern margins, and the margins of adjacent physiographic regions to the east and south (see Collins 1995, 2004 for review). An understanding of the area's archeological record has been obtained through several large-scale projects, primarily reservoir salvage projects 


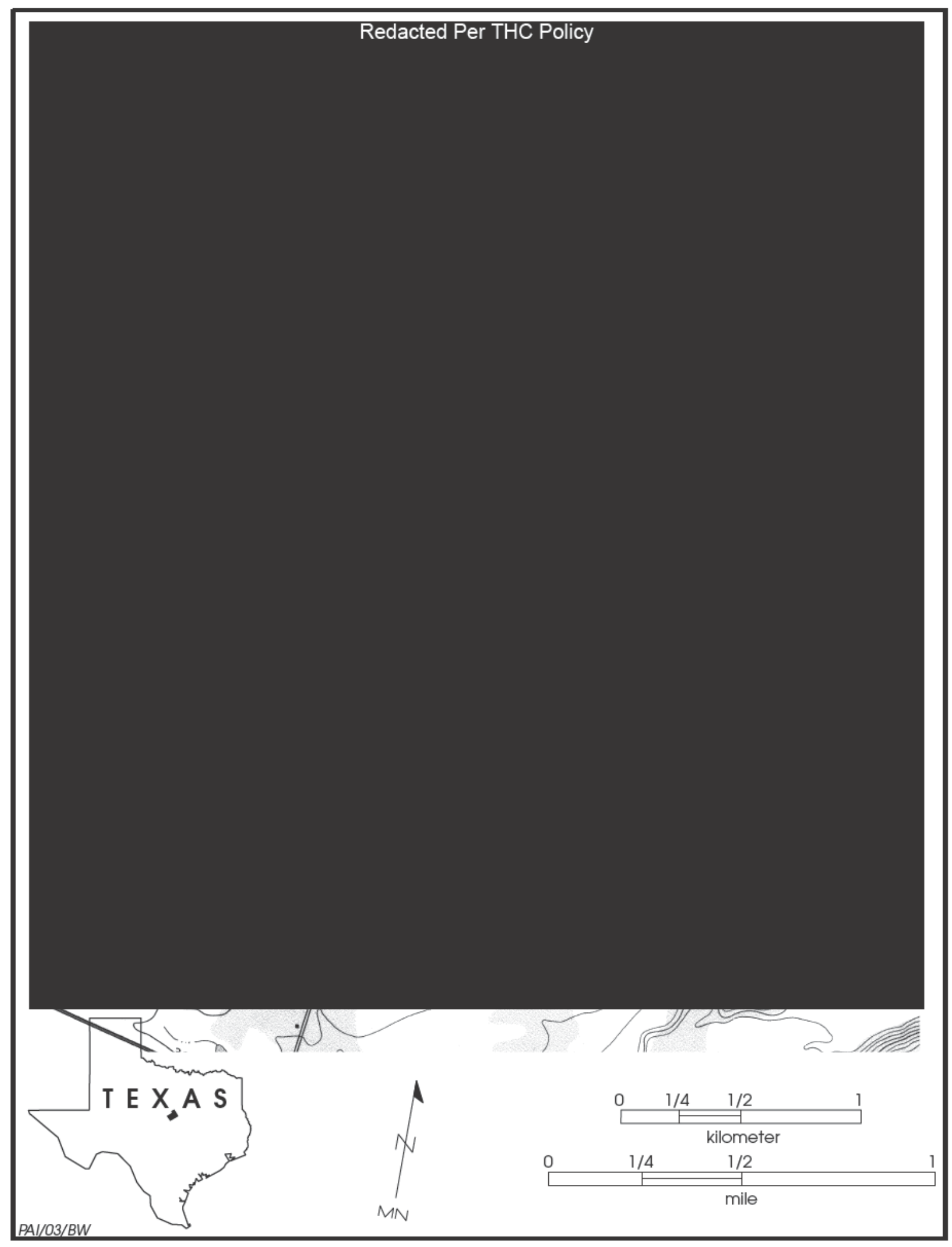

Figure 1. Project location map showing 41HM46. 


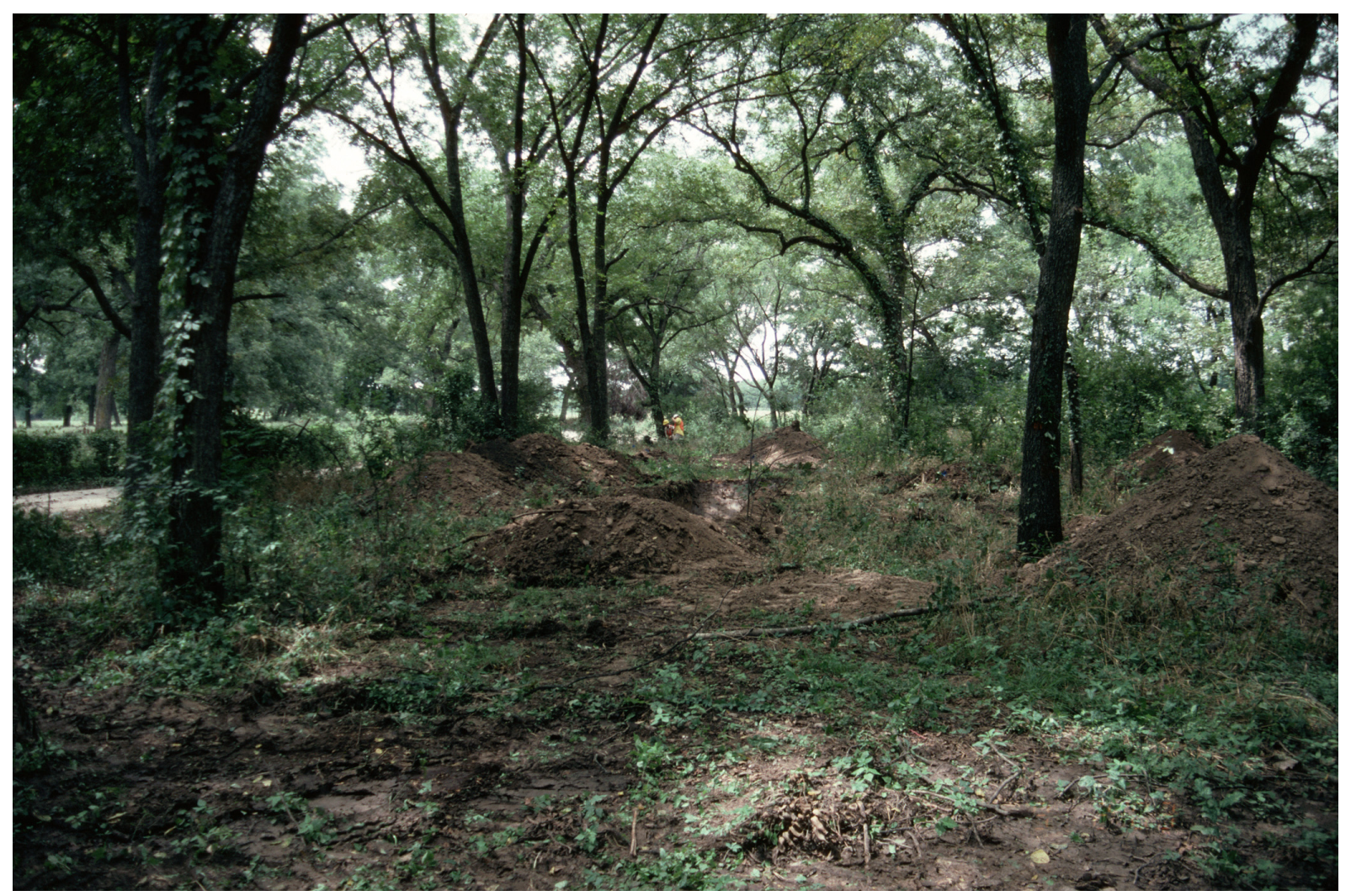

Figure 2. Site 41HM46 looking southwest.

such as Whitney Lake (Jelks 1953, 1962; Stephenson 1947, 1970) and Aquilla Lake (Brown 1987; Lynott and Peter 1977; Skinner et al. 1978; Skinner and Henderson 1972) to the east; Hog Creek Reservoir (Hays and Kirby 1977; Henry 1995; Henry et al. 1980; Larson et al. 1975; Larson and Kirby 1976; Shafer 1977) to the northeast; and Stillhouse Hollow Reservoir (Sorrow et al. 1967), Belton Lake (Miller and Jelks 1952; Shafer et al. 1964), and Fort Hood (Abbott and Trierweiler 1995; Kleinbach et al. 1999; Mehalchick et al. 1999, 2000; Trierweiler $1994,1996)$ to the south-southeast. Kvernes et al. (2000:7-12) provide summaries of these projects, which helped to establish the prehistoric cultural sequence of the area that we understand and recognize today. Generally, this cultural sequence is divided into three periods: Paleoindian, Archaic, and Late Prehistoric (see Collins 1995; Johnson and Goode 1994; Prewitt 1981, 1985).

Paleoindian (11,500-8800 B.P.) occupations of the central Texas region are represented by surficial and deeply buried sites, rockshelter sites, and isolated artifacts. The period is often described as having been characterized by small but highly mobile bands of foragers who were specialized hunters of Pleistocene megafauna. However, a more accurate view of Paleoindian lifeways probably includes the utilization of a much wider array of resources. Recent investigations at the Wilson-Leonard site (41WM235) support this view and have challenged the fundamental defining criteria of the Paleoindian period, that of artifacts in association with late Pleistocene megafauna (Collins 1998).

Collins (1995) divides the Paleoindian period into early and late subperiods. Two projectile point styles, Clovis and Folsom, are included in the early subperiod. For decades researchers believed that Clovis artifacts were the material remains of the initial inhabitants of the continent. However, recent investigations at the Gault (Collins and Bradley 2008) and Friedkin (Waters et al. 2011) sites in Bell County, and other sites across North America, have yielded cultural materials below Clovis levels with accompanying radiocarbon ages that predate Clovis. Currently, little is known about these pre-Clovis peoples, but it is becoming clear 
that they were widespread across the continent centuries before Clovis hunters and gatherers roamed North America.

Clovis chipped stone artifact assemblages, including the diagnostic fluted lanceolate Clovis point, were produced by bifacial, flake, and prismatic-blade techniques on high-quality and oftentimes exotic lithic materials (Collins 1990). Along with chipped stone artifacts, Clovis assemblages include engraved stones, bone and ivory points, stone bolas, and ochre (Collins 1995:381; Collins et al. 1992). Clovis, as well as a number of later Paleoindian dart points, have been recovered from the Gault site in Bell County (Collins 1998) and the Triple S Ranch site in Hamilton County (Hatfield 1997). Probable Clovis polyhedral blade cores have been found in Hamilton County (Goode and Mallouf 1991). Analyses of Clovis artifacts and site types suggest that Clovis peoples were well-adapted, generalized hunter-gatherers with the technology to hunt larger game but not solely rely on it. In contrast, Folsom tool kits, consisting of fluted Folsom points, thin unfluted (Midland) points, large thin bifaces, and end scrapers, are more indicative of specialized hunting, particularly of bison (Collins 1995:382). Folsom points have been recovered from Horn Shelter No. 2 along the Brazos River in Bosque County (Redder 1985; Watt 1978).

Postdating Clovis and Folsom points in the archeological record are a series of dart point styles for which the temporal, technological, or cultural significance is unclear. Several of these styles were recovered from Wilson-Leonard and Horn Shelter No. 2 and Angostura, Wilson, Plainview, Scottsbluff, Dalton, and San Patrice (Watt's [1978] Brazos Fishtail points). Often the Plainview type name is given to any unfluted lanceolate dart point; however, Collins (1995:382) has noted that many of these points typed as Plainview do not parallel Plainview type-site points in thinness and flaking technology. Also problematic are the chronological position and cultural significance of Dalton and San Patrice dart points. Components and artifact and feature assemblages of the later Paleoindian subperiod appear to be Archaic-like in nature and in many ways may represent a transition between the early Paleoindian and succeeding Archaic periods (Collins 1995:382).

The Archaic period for central Texas dates from ca. 8800 to $1300-1200$ B.P. (Collins 1995).
The Archaic period is generally believed to represent a shift toward the hunting and gathering of a wider array of animal and plant resources and a decrease in group mobility (Willey and Phillips 1958:107-108). In the eastern and southwestern U.S. and on the Great Plains, the Archaic period is succeeded by the development of horticulturalbased, semisedentary to sedentary societies. In these areas the Archaic truly represents a developmental stage of adaptation as Willey and Phillips (1958) define it. For central Texas, this notion of the Archaic is somewhat problematic. The evidence suggests that Archaic-like adaptations were in place prior to the Archaic (see Collins 1995:381-382; Collins 1998; Collins et al. 1990) and that these practices continued into the succeeding Late Prehistoric period (Collins 1995:385; Prewitt 1981:74). In this sense, the Archaic period of central Texas is not a developmental stage but an arbitrary chronological construct and projectile point style sequence. The establishment of this sequence is based on several decades of archeological investigations at stratified Archaic sites along the eastern and southern margins of the Edwards Plateau. Collins (1995) and Johnson and Goode (1994) have divided this sequence into three parts-early, middle, and late- based on perceived (though not fully agreed upon by all scholars) technological, environmental, and adaptive changes.

Early Archaic (8800-6000 B.P.) sites are small and their tool assemblages are very diverse (Weir 1976:115-122), suggesting that populations were highly mobile and densities low (Prewitt 1985:217). Early Archaic sites are concentrated along the eastern and southern margins of the Edwards Plateau (Johnson and Goode 1994; McKinney 1981). This distribution may be indicative of climatic conditions at the time, given that these environments have many more reliable water sources and a diverse resource base. Early Archaic projectile point styles include Gower, Wells, Martindale, and Uvalde. Manos, metates, hammerstones, Clear Fork and Guadalupe bifaces, and a variety of other bifacial and unifacial tools are common to Early Archaic assemblages. The construction and use of rock hearths and ovens reflect a specialized subsistence strategy (exploitation of geophytes) during the Early Archaic as witnessed at the WilsonLeonard site (Collins 1998:252-262). These burned rock features most likely represent the technological predecessors of the larger burned 
rock middens that developed extensively later in the Archaic period (Collins 1995:383). Significant Early Archaic sites include the Youngsport site in Bell County (Shafer 1963), which yielded Gower and Wells dart points from deeply buried contexts.

During the Middle Archaic period (6000 4000 B.P.), the number and distribution of sites, as well as site size, increased due to probable increases in population densities (Prewitt 1981:73; Weir 1976:124, 135). Macrobands may have formed at least seasonally, or an increased number of small groups may have utilized the same sites for longer periods of time (Weir 1976:130-131). A greater reliance on plant foods is suggested by the presence of burned rock middens toward the end of the Middle Archaic, although tool kits still imply a strong reliance on hunting (Prewitt 1985:222-226). Middle Archaic projectile point styles include Bell, Andice, Taylor, Baird, Nolan, and Travis. Bell and Andice points reflect a shift in lithic technology from the preceding Early Archaic Martindale and Uvalde point styles (Collins 1995:384). Johnson and Goode (1994:25) suggest that the Bell and Andice darts were parts of a specialized bisonhunting tool kit. They also suggest that the beginning of the Middle Archaic was marked by an influx of bison and bison-hunting groups from the Eastern Woodland margins during a slightly more mesic period. Bell points and bison remains were recovered from the Landslide site in Bell County (Sorrow et al. 1967). Bison disappeared, or were reduced in number, as more xeric conditions returned during the later part of the Middle Archaic. Later Middle Archaic projectile point styles represent another shift in lithic technology (Collins 1995:384; Johnson and Goode 1994:27). This interval also saw a shift to more xeric conditions and the development of burned rock middens, the masses of burned rocks left over from multiple episodes of baking and cooking with hot rock hearths and ovens. Johnson and Goode (1994:26) believe that the dry conditions promoted the spread of xerophytic plants, such as yucca and sotol, and that these plants were collected and cooked in large rock ovens by late Middle Archaic peoples. More recent data however suggests that the rock hearths and ovens were used to process geophytes, plants with edible underground food storage organs such as bulbs and tubers (see Mehalchick et al. 2004:211-219).
During the succeeding Late Archaic period (4000 to 1300-1200 B.P.), populations continued to increase (Prewitt 1985:217). Packing of the landscape, smaller territories, and restricted residential mobility were offset by more efficient uses of resources and greater site use intensity (Kibler and Mehalchick 2010). Within stratified Archaic sites, such as Youngsport and Landslide, the Britton, Higginbotham, and McMillan sites in McLennan County (Story and Shafer 1965, Mehalchick and Kibler 2008), and the Steele site in Hill County (Stephenson 1970), the Late Archaic components contain the densest concentrations of cultural materials. The establishment of large cemeteries along drainages suggests strong territorial ties by certain groups (Story 1985:40). A variety of projectile point styles appeared throughout the Late Archaic period. Johnson and Goode (1994:29-35) divide the Late Archaic into two parts, Late Archaic I and Late Archaic II, based on increased population densities and perceived evidence of Eastern Woodland ceremonial rituals and religious ideological influences. Middle Archaic subsistence technology, including the development of burned rock middens, continued into the Late Archaic period. Collins (1995:384) states that, at the beginning of the Late Archaic period, the construction and use of burned rock middens reached its zenith and that their use declined during the latter half of the Late Archaic. However, there is mounting data that midden formation and use culminated much later and that this high level of use continued into the early Late Prehistoric period (Black et al. 1997:270-284; Kleinbach et al. 1995:795). A picture of prevalent burned rock midden development in the eastern part the central Texas region after 2000 B.P. is becoming clear. This parallels the widely recognized occurrence of post-2000 B.P. middens in the western reaches of the Edwards Plateau (see Goode 1991). The use of rock hearths and ovens, resulting in the development of burned rock middens, appears to have been a major part of the subsistence strategy as a decrease in the importance of hunting, inferred from the low ratio of projectile points to other tools in site assemblages, may have occurred (Prewitt 1981:74).

The Late Prehistoric period (1300-1200 to 300 B.P.) is marked by the introduction of the bow and arrow and, later, ceramics into central Texas. Population densities dropped considerably from their Late Archaic peak (Prewitt 
1985:217). Subsistence strategies did not differ greatly from the preceding period, although bison became an important economic resource during the later part of the Late Prehistoric period (Prewitt 1981:74). The use of rock hearths and ovens for plant food processing and the resulting development of burned rock middens continued throughout the Late Prehistoric period (Black et al. 1997; Kleinbach et al. 1995:795). Horticulture came into play very late in the region but was of minor importance to overall subsistence strategies (Collins 1995:385).

In central Texas the Late Prehistoric period is generally associated with the Austin and Toyah phases (Jelks 1962; Prewitt 1981:82-84). Much of what we know about the Austin and Toyah phases comes from rockshelter sites in and around Lake Whitney in Bosque and Hill Counties (see Jelks 1962; Stephenson 1970). Austin and Toyah phase horizon markers, Scallorn-Edwards and Perdiz arrow points, respectively, are distributed across most of the state. The introduction of Scallorn and Edwards arrow points into central Texas was often marked by evidence of violence and conflict, as many excavated burials contain these point tips in contexts indicating that they were the cause of death (Prewitt 1981:83). Subsistence strategies and technologies (other than arrow points) did not change much from the preceding Late Archaic. This continuity is recognized by Prewitt's (1981) use of the term "Neoarchaic." In fact, Johnson and Goode (1994:39-40) and Collins (1995:385) state that the break between the Late Archaic and the Late Prehistoric could be appropriately represented by the break between the Austin and Toyah phases.

Around 1000-750 B.P., slightly more xeric or drought-prone climatic conditions returned to the region, and bison returned in large numbers (Huebner 1991; Toomey et al. 1993). Utilizing this vast resource, Toyah phase peoples were equipped with Perdiz point-tipped arrows, end scrapers, four-beveled-edge knives, and plain bone-tempered ceramics. The technology and subsistence strategies of the Toyah phase represent a completely different tradition than the preceding Austin phase. Collins (1995:388) states that burned rock middens fell out of use as bison hunting and group mobility obtained a level of importance not witnessed since Folsom times. While the importance of bison hunting and high group mobility can hardly be disputed, the cessation of burned rock midden development during the Toyah phase is tenuous. An examination of Toyah-age radiocarbon assays and assemblages by Black et al. (1997) suggests that their association with burned rock middens represents more than a "thin veneer" capping Archaic-age features. Black et al. (1997) claim that rock hearth and oven use resulting in burned rock middens, while not as prevalent as in earlier periods, played a role in the adaptive strategies of Toyah peoples.

Contact with Caddoan groups to the east and northeast during the Late Prehistoric period is represented by the presence of Caddoan ceramics in site assemblages, particularly in the eastern peripheral areas of central Texas (e.g., Stephenson 1970). These interactions are particularly evident in the middle Brazos River valley, although the social dynamics are far from clear. Story (1990:364), in her overview of the middle Brazos River basin, argues for a period/ horizon characterized by Alba points and Early to Middle Caddoan-like pottery intermediate between the Austin and Toyah phases. Although Story did not elaborate further on the cultural dynamics responsible for this archeological pattern, she noted that evidence of this proposed archeological manifestation was found at the Chupik (Watt 1953) and Asa Warner sites (Watt 1956; Wright 1997) in McLennan County. The Jayroe site (41HM51), across the Leon River from 41HM46, with its brushed Caddoan-like pottery may be another site that is part of this archeological pattern (see Kibler and Broehm 2005). More recently, Shafer (2006) has developed this idea into the "Prairie Caddo" model. He suggests that groups in the middle Brazos River valley between A.D. 1000 and 1300 were Caddo peoples who served as the sustaining population for the ceremonial center at the George C. Davis site. The basis for Shafer's model is the lack of contemporaneous habitation sites near the Davis site and the occurrence of a suite of artifacts (e.g., Caddo ceramic vessels, Alba and Bonham arrow points, Gahagan knives, and bone needles and metapodial beamers) at certain sites in the middle Brazos River valley that are viewed as the material culture of ethnic Caddo groups. Recent geochemical data on Caddo-like pottery sherds from site 41BQ285 indicate that the vessels were made at or near the site rather than by the Caddo in east Texas (Griffith et al. 2010). This evidence seems to support the Prairie 
Caddo model, although the Late Prehistoric component at 41BQ285 largely postdates Shafer's (2006) Prairie Caddo time period, as well as Story's (1990) intermediate Late Prehistoric period. Clearly, for this area of central Texas the archeological constructs of the Austin and Toyah phases are of limited value in terms of the social dynamics, which appear to be much more complex than previously thought.

\section{Previous Investigations}

\section{$41 H M 46$}

Site 41HM46 was originally recorded during a survey for the proposed CR 294 bridge replacement on the south side of the Leon River (Kibler 2003). Two 7-m-long backhoe trenches were placed on the $\mathrm{T}_{1}$ terrace within the proposed right of way. Backhoe Trench 1, located $15 \mathrm{~m}$ south of the edge of the terrace, showed no evidence of cultural remains. Backhoe Trench 2, placed $12 \mathrm{~m}$ southwest of BHT 1 and near the southwest corner of the project area, uncovered a dark paleosol ca. $90 \mathrm{~cm}$ below the ground surface. Burned rocks, pieces of charcoal, and freshwater mussel shells were observed in this buried soil, which was determined to be at least $85 \mathrm{~cm}$ thick. No diagnostic artifacts or features were observed. The horizontal extent of the site to the north, south, and west could not be determined due to the limits of the project area. The northeastern/eastern extent of the buried soil was also undetermined, but the trench profiles suggested that the paleosol had been truncated to the north/northeast and the area backfilled with more recent alluvium, forming an erosional unconformity beneath the $\mathrm{T}_{1}$ terrace surface somewhere between BHT 1 and BHT 2. It was therefore believed that the northeastern/eastern edge of 41HM46 also lies somewhere between these two trenches.

The results of the survey indicated that the cumulic nature of the buried soil had the potential to contain discrete artifact assemblages and features. Further, the soil's burial by subsequent alluvial deposition suggested that the site's context was undisturbed. Therefore, $41 \mathrm{HM} 46$ was considered to have the potential to contribute important information concerning Texas prehistory and be potentially eligible for listing in the National Register. Test excavations were recommended (Kibler 2003).

\section{Other Sites in the Vicinity of $41 H M 46$}

The Texas Historical Commission's Archeological Sites Atlas was consulted to review information on previously recorded archeological sites within a $2-3 \mathrm{~km}$ vicinity of $41 \mathrm{HM} 46$. The only sites recorded are 41HM51, 41HM52, 41HM54, and 41HM60.

Site $41 \mathrm{HM} 51$ is opposite $41 \mathrm{HM} 46$ on the north side of the Leon River within the CR 294 bridge replacement project area. The site was recorded in November 2003 and recommended for testing (Broehm et al. 2004). Test excavations recovered 1 Ensor dart point, 3 Perdiz points, 1 possible Perdiz point, 1 unidentified arrow point fragment, 7 bifaces, 1 uniface, 1 core, 3 edgemodified flakes, 1 ground stone tool, 2 modified bones, 1 piece of cut mussel shell, 5 ceramic sherds, 299 pieces of lithic debris, 388 mussel shell umbos, and more than 486 pieces of animal bone. A single piece of ochre was also collected, and 723 burned rocks, predominantly limestone, were documented in the field. Based on the characteristics and nature of the Toyah component at the site, 41HM51 was judged eligible for listing in the National Register (Broehm et al. 2004:35). Data recovery excavations were recommended for the Toyah component since bridge construction impacts could not be avoided.

Data recovery excavations at 41HM51 were conducted April through July 2004 (Kibler and Broehm 2005). Given that the Toyah materials rested on top of a soil buried by recent alluvial sediments up to a ca. $1 \mathrm{~m}$ thick, excavations began with the mechanical stripping of the overlying sediments to within $30 \mathrm{~cm}$ of the top of the buried soil over a $256 \mathrm{~m}^{2}$ area. South of the stripped area, two gradall trenches were excavated to the top of the soil. Within the stripped area and the two trenches, $1551 \times 1$ $\mathrm{m}$ excavation units were dug by hand. The excavations recovered 63 projectile points, most of which were Perdiz arrow points, including fragments and preforms. Other chipped stone tools included 266 bifaces (including beveled knives), unifaces (including end scrapers), and edge-modified flakes. Four cores and approximately 6,265 pieces of chert debitage also were recovered. While the chipped stone assemblage overwhelmingly were of chert, it also included six pieces of obsidian. Other tools and cultural materials recovered consisted of 15 ground and 
battered stone tools and tool fragments, 44 pottery sherds, approximately 5,203 vertebrate faunal remains, and 715 freshwater mussel shell umbos. Nine features were encountered, consisting of basin-shaped hearths, bone clusters, burned rock concentrations, an ash and oxidized sediment lens, and clusters of burned rocks, flakes, and broken tools.

Site 41HM52 was documented by THC Steward Frank Sprague as a river terrace campsite. The site occupies a low sandy ridge on the north side of the Leon River just east of the confluence of the Leon River and Warrens Creek and downstream (east) of 41HM46. Site size was estimated at 25 acres. Based on field observations and discussions with informants, 41HM52 was identified as a multicomponent site from which several burials had been removed. Cultural materials observed included burned rocks, bones, mussel shells, debitage, and biface fragments. Paleoindian materials had been reported from a 1-acre area on the south side of the site, but there is no additional information on the nature and character of these materials. Portions of the site have been disturbed by gravel mining, roads, and building construction.

The Upper Sprague site (41HM54), on the western bank of a south-draining tributary of the Leon River, was the focus of research of several Baylor University archeological field schools between 2007 and 2010 (Baylor University n.d.). The site was originally recorded in 2004 by Bryan Jameson of the Texas Archeological Stewardship Network. At that time it was recorded as a multicomponent site dating from the Early Archaic to the Late Prehistoric, based on diagnostic projectile points and examination of cut banks, auger tests, and backhoe trenches. Diagnostics recovered included a Clear Fork gouge; Bulverde, Yarbrough, Nolan, Pedernales, and Williams dart points; and a Bonham arrow point. Work by Baylor University confirmed the presence of a Middle Archaic to Late Prehistoric occupation sequence. As of 2009, a total of $42 \mathrm{~m}^{2}$ of site area had been excavated, yielding 13 discrete features and a number of diagnostic artifacts. Well-defined contexts dating from the late Austin and early Toyah phases have been investigated. Features included a basin-shaped hearth, a flat stone concentration, a Rabdotus snail shell cluster, an arc-shaped burned daub concentration that may represent a structure, and five flaked chert cobbles. Primarily Scal- lorn and Perdiz points were recovered, along with Cliffton, Harrell, Alba, and Fresno arrow points. Faunal remains included bison, medium to small-sized mammals, turtles, and fish.

Site 41HM60, a prehistoric open campsite east of 41HM46, was identified during a survey by Horizon Environmental Services, Inc. No diagnostic artifacts were noted, but observed materials included burned rocks, mussel shells, lithic debris, small to medium-sized mammal bones, and charcoal. The site is suspected to be multicomponent based on well-stratified cultural zones on the north and south terraces of Waring Creek.

Although limited in number and data, these sites indicate the potential for buried intact and stratified cultural remains along portions of the Leon River, particularly in the vicinity of confluences with tributary streams.

\section{METHODOLOGY}

Test excavations at 41HM46 consisted of three backhoe trenches, eight shovel tests, and seven $1 \times 1-m$ test units placed within the trenches (Figure 3). The investigations began with the excavation of the backhoe trenches. Backhoe trench excavations extended to approximately the top of the paleosol, which varied from 60 to $140 \mathrm{~cm}$ below the ground surface. Backhoe Trench 3 was placed between BHT 1 and BHT 2, which were excavated during the original survey. It measured $12.7 \mathrm{~m}$ long, $2.2 \mathrm{~m}$ wide, and $1.4 \mathrm{~m}$ deep. Its purpose was to find the northeastern edge of the paleosol and erosional unconformity and to remove the deposits overlying the paleosol so hand excavations could commence from the top of the paleosol. BHTs 4 and 5 were excavated to remove the more recent alluvial deposits overlying the paleosol so hand excavation of test units could start at the top of the paleosol. Backhoe Trench 4 was placed ca. $7 \mathrm{~m}$ southwest of BHT 3. It measured $5.0 \mathrm{~m}$ long, $2.5 \mathrm{~m}$ wide, and $1.2 \mathrm{~m}$ deep. Backhoe Trench 5 was placed ca. $3 \mathrm{~m}$ northwest of BHT 3. It measured $5.0 \mathrm{~m}$ long, $2.2 \mathrm{~m}$ wide, and $0.6 \mathrm{~m}$ deep.

Once the edge of the paleosol and erosional unconformity were defined, eight shovel tests were excavated at irregular intervals across the site. Shovel test excavations began at the ground surface and extended to a depth of $100 \mathrm{~cm}$ or to the top of the paleosol, whichever came first. Shovel tests were dug to ascertain if cultural 


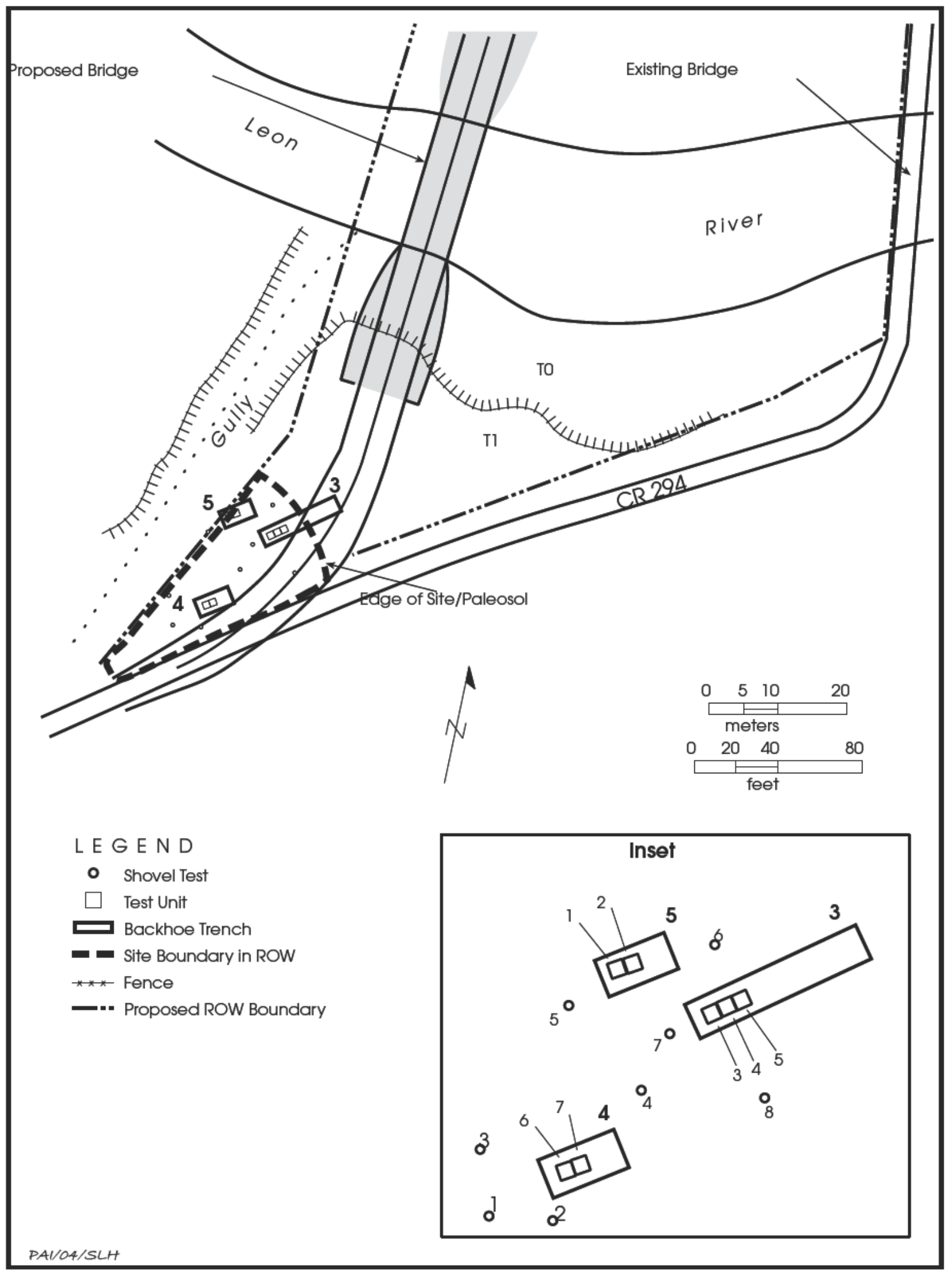

Figure 3. Site map of 41HM46 showing the locations of backhoe trenches, shovel tests, and test units. 
materials were contained in the more-recent alluvial deposits overlying the paleosol. Shovel tests were excavated in 20-cm-thick levels, and all sediment was screened through 1/4-inchmesh hardware cloth. Sediment descriptions, any artifacts collected or observed, and other features of interest were recorded on a standard form for each shovel test.

Next seven $1 \mathrm{x} 1-\mathrm{m}$ test units were hand excavated, beginning at the top of the paleosol at the bottom of the trenches and extending to a depth of $100 \mathrm{~cm}$ below the top of the paleosol. Test Units 1 and 2 were placed adjacent to one another in BHT 5, forming a 1x2-m block. Test Units 3,4 , and 5 , were placed adjacent to one another in BHT 3 at its western end, forming a 1x3-m block. Test Units 6 and 7 were placed in BHT 4 also adjacent to one another, forming a 1x2-m block.

Test units were excavated in 10-cm levels. A datum was placed at the highest corner of the unit, and each level was measured from a level line originating at that point. In this way, elevations were taken from near the top of the paleosol. All soil was screened through $1 / 4$-inchmesh hardware cloth. Soil descriptions, artifacts collected or observed, disturbances, and other features of interest were recorded on a standard level form for each test unit.

Artifacts collected were bagged separately by level and unit and returned to the PAI laboratory for processing. Counts of collected artifacts were made at the time of excavation in order to acquire some in-field understanding of artifact frequency and distribution. Burned rocks and Rabdotus shells were counted and weighed in the field and then discarded. A topographic map depicting the locations of backhoe trenches, shovel tests, and test units at the site was completed using a Sokkia SET 5F total mapping station.

\section{RESULTS OF INVESTIGATIONS}

\section{Sediments and Stratigraphy}

A broad alluvial surface extends across and beyond the boundaries of the bridge project area (Figure 4). On the south side of the Leon River, at site $41 \mathrm{HM} 46$, this $\mathrm{T}_{1}$ terrace surface stands about $5 \mathrm{~m}$ above the channel. On the north side of the river, at site $41 \mathrm{HM} 51$, the $\mathrm{T}_{1}$ surface is divided into $\mathrm{T}_{1 \mathrm{a}}$ and $\mathrm{T}_{1 \mathrm{~b}}$ components by a low scarp approximately $1 \mathrm{~m}$ in height (Kibler and Broehm 2005:18). Backhoe trench and test unit profiles revealed that at least two alluvial units underlie the $\mathrm{T}_{1}$ terrace surface at $41 \mathrm{HM} 46$. The younger alluvium is laterally inset to and draped over the older unit. The older alluvial unit is capped by a cumulic, buried soil, the top of which is 60 to $140 \mathrm{~cm}$ below the $\mathrm{T}_{1}$ surface, and is marked by an erosional unconformity where the younger fill is laterally inset to the older unit. At 41HM51, alluvium below the $\mathrm{T}_{1 \mathrm{~b}}$ surface is laterally inset to and draped over an older unit below the $\mathrm{T}_{1 \mathrm{a}}$ surface. As at 41HM46, the older alluvial unit is capped by a cumulic, buried soil, the top of which is 60 to $200 \mathrm{~cm}$ below the $\mathrm{T}_{1 \mathrm{a}}$ surface.

The younger alluvial unit, based on observations of BHT 3 and associated Test Unit 3-5 profiles, exhibits an ca. $95 \mathrm{~cm}$-thick $\mathrm{A}-\mathrm{Bw}$ soil (Figure 5). The A horizon is a ca. 20-cm-thick dark grayish brown (10YR4/2) silty clay loam with a weak fine granular structure. The $\mathrm{Bw}$ horizon is a ca. 80 -cm-thick brown (10YR5/3) silty clay loam exhibiting a moderate fine blocky subangular structure. A few thin beds of sand were observed throughout the $\mathrm{Bw}$ horizon. The age of this unit is somewhat nebulous. Based on Nordt's (1992) work on the Leon River at Fort Hood, however, this alluvial unit probably is analogous to his Ford alluvial unit, which drapes and is laterally inset to the older West Range unit. This suggests that the alluvial mantle at $41 \mathrm{HM} 46$ is less than 600 to 800 years old. At 41HM51, Perdiz points, ceramics, and associated radiocarbon ages of 210 to 680 B.P. were encapsulated at the base of the younger alluvial unit resting on the surface of the pedogenically altered older alluvial unit.

The older unit, again based on observations of the BHT 3 and associated Test Units $3-5$ profiles, is imprinted with a $2 \mathrm{Ab}-2 \mathrm{Bb}$ soil. The $2 \mathrm{Ab}$ horizon is a 60 -cm-thick very dark gray (10YR3/1) clay loam. It displays a weak medium prismatic structure that breaks to a moderate fine blocky angular structure and common insect burrow casts. The soil is cumulic in nature and yielded most of the cultural materials recovered from $41 \mathrm{HM} 46$. The underlying $2 \mathrm{Bb}$ horizon is a very dark grayish brown (10YR3/2) silty clay loam to clay loam. It also exhibits a weak medium prismatic structure that breaks to a moderate fine blocky angular structure. The age of the older unit is a little problematic, though the recovery of an Ensor dart point from the 


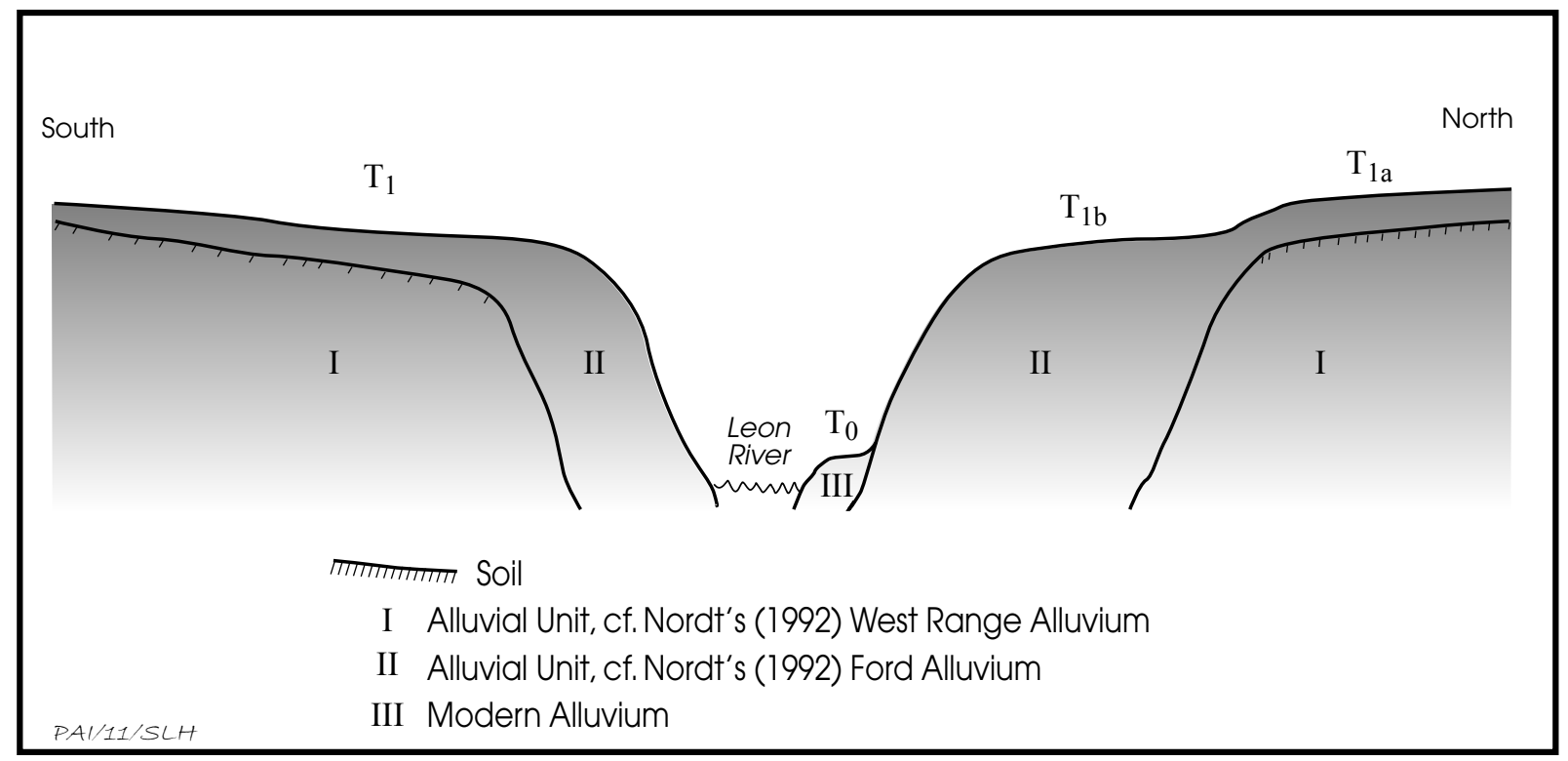

Figure 4. Schematic of the project area's geomorphology and stratigraphy.

paleosol imprinted on the unit suggests that floodplain aggradation ceased or slowed around ca. 1,700 to 1,500 years ago. An Ensor point was also recovered from the paleosol at 41HM51 during testing (Kibler and Broehm 2005:18). The paleosol is similar to the Leon River paleosol identified downstream at Fort Hood in its pedogenic characteristics and geomorphic position (Mehalchick et al. 1999). The Leon River paleosol is a cumulic soil imprinted on the late Holocene West Range alluvium, which Nordt (1992) dates to 4300 to $800 / 600$ B.P. Radiocarbon ages on bulk humates from the Leon River paleosol range from $1160 \pm 40$ to $1010 \pm 70$ B.P. (Mehalchick et al. 1999:215; Nordt 1992). Based on the investigations at sites 41HM46 and 41HM51 and downstream at Fort Hood, it would appear that floodplain stability occurred throughout much of the Leon River valley sometime between 1200 and 600 B.P.

\section{Excavations Accomplished}

Backhoe Trench 3 shows the northeastern extent of 41HM46 within the proposed right of way extending ca. $6.5 \mathrm{~m}$ from the western end of the trench. The intervening $20-25 \mathrm{~m}$, from the edge of the terrace to the edge of the paleosol and erosional unconformity, consists of more recent Late Holocene alluvial fill (c.f., Nordt's [1992] Ford alluvium) following the lateral truncation of the paleosol. The paleosol was also identified in BHTs 4 and 5, showing that the site probably extends over the remaining part of the project area. The horizontal extent of the site within the boundaries of the proposed right of way covers ca. $1,050 \mathrm{~m}^{2}$. However, the extent of the site to the north, south, and west outside the boundaries of the project area remains unknown.

Shovel testing of the alluvial deposits overlying the paleosol did not yield any cultural materials. The buried soil was encountered in only two shovel tests, STs 5 and $6(56 \mathrm{~cm}$ and $85 \mathrm{~cm}$ below surface, respectively). The remaining shovel tests were excavated to $100 \mathrm{~cm}$ below surface with the exception of ST 1, which was excavated to $70 \mathrm{~cm}$ below surface.

Test unit excavations revealed little disturbance in the paleosol. Some linear sandy inclusions were noted in the upper $50 \mathrm{~cm}$ of Test Units 3 and 5 . These may be the remnants of tree root casts or rodent burrows. Evidence of a rodent burrow in the form of a small $10 \mathrm{~cm}^{2}$ pocket of limestone gravels was observed in Test Unit 2, Level 4. Several rodent mandibles were observed in the faunal assemblage recovered at $41 \mathrm{HM} 46$. No other disturbances were noted in any of the test units.

In Test Units 1-5, the bottom of the A horizon of the paleosol was encountered between 70 and $80 \mathrm{~cm}$ below datum (cmbd). The last $20-30 \mathrm{~cm}$ of the clay loam were noticeably 


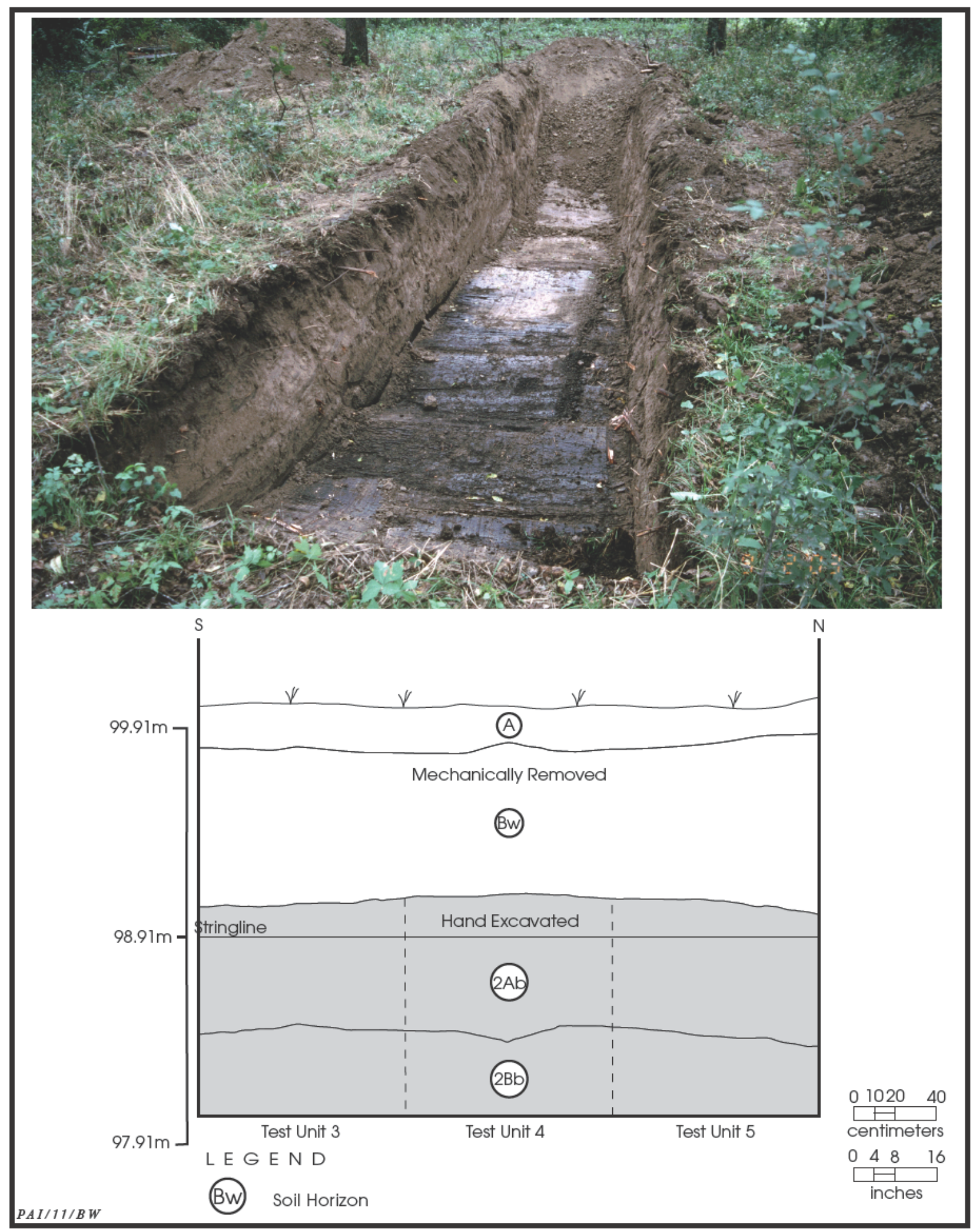

Figure 5. Overview of Backhoe Trench 3 with the buried soil exposed across the bottom of the trench and the west wall profile of Test Units 3-5. 
more brown and more compacted. Excavations continued into this matrix. The bottom of the A horizon was not encountered at $100 \mathrm{cmbd}$ in Test Units 6 and 7, although the first levels in these units commenced slightly above the paleosol. Nonetheless, excavation was terminated at $100 \mathrm{cmbd}$ in these units.

The hand excavations of the test units totaled $7 \mathrm{~m}^{3}$. Artifact counts were low throughout $41 \mathrm{HM} 46$, and only two features were recorded. Artifacts consisted of chipped stone tools, cores, unmodified debitage, freshwater mussel shell umbos, bones, burned clay, burned limestone rocks, and charcoal. Artifacts were recovered from both the A and B horizons of the paleosol, although generally in decreasing frequency in the latter.

\section{Features}

Two features were recorded. They were not recognized as features during the fieldwork but were assessed as such after fieldwork was completed. Feature 1 was uncovered near the northeast corner of Test Unit 2 between 89 and $91 \mathrm{cmbd}$. It consisted of a ca. $20 \mathrm{~cm}^{2}$ concentration of five small burned limestone rocks. The concentration extended into the northern wall of the unit. The burned rocks weigh $0.9 \mathrm{~kg}$. No charcoal, burned clay, or discolored soil was directly associated with this concentration, although four small pieces of burned clay and a piece of charcoal were collected from Level 9 . No artifacts were directly associated with this feature, and artifact counts showed an overall decrease from the previous level in this unit, with the exception of burned rocks (including the concentration), which increased over the previous level $(\mathrm{n}=6$ versus $\mathrm{n}=11)$.

Feature 2 consisted of four to six burned rocks and a piece of chert scattered across the eastern $40 \mathrm{~cm}$ of the unit. It was encountered in Test Unit 2 at $70-80 \mathrm{cmbd}$. As noted above, the total weight of these rocks was $1.0 \mathrm{~kg}$. No artifacts, charcoal, burned clay, or discolored soil were directly associated with this feature, although this level showed the greatest overall artifact recovery within the unit. An Ensor dart point and two retouched flakes were recovered from the level. The scatter of burned rocks appears to extend eastward outside the excavation unit.

The original morphology, content, and function of these features are unclear. They may represent the edges of more clearly delineated features outside the excavated areas or highly dispersed remnants of features.

\section{Artifacts and Other Materials}

Artifacts recovered from 41HM46 consist of 1 Ensor dart point, 4 bifaces, 2 cores, 2 edge-modified flakes, 114 pieces of unmodified debitage, 245 freshwater mussel shell umbos, and 264 pieces of bone weighing $248.8 \mathrm{~g}$ (Table 1). In addition, 280 burned limestone rocks, 5 pieces of thermally shattered chert, and 1 piece of thermally altered petrified wood were recovered from the seven test units. The total weight of burned rocks was approximately $11.4 \mathrm{~kg}$. A total of $35 \mathrm{~g}$ of burned clay was collected (data not presented in Table 1) but more, which could not be easily collected, was observed during excavations. Macrobotanical remains recovered from the site were limited. Occasional small pieces of charcoal were observed in Test Units 1 and 2, but only one piece could be collected. The density of different artifact categories per cubic meter varied considerably among lithic artifacts but was quite similar among bones, mussel shells, and burned rocks (see Table 1 ).

\section{Projectile Points}

An Ensor dart point was recovered from Test Unit 2, Level 8 (Figure 6a). The mottled gray chert point is nearly complete and may have been manufactured from a heat-treated flake or bifacial preform. The tip has been lost subsequent to a transverse bending fracture, and the base was slightly damaged during excavation. The Ensor point is a ubiquitous style found throughout central and south Texas during the later part of the Late Archaic (Turner and Hester 1993:114). Its temporal span fits within that of the Leon River paleosol. The Ensor point provenience is associated with an increase in artifact density in Levels 7 and 8.

\section{Other Lithic Tools and Cores}

Six additional lithic tools (consisting of four bifaces and two edge-modified flakes) and two cores were recovered. One biface, recovered from Test Unit 5, Level 2, may represent the blade of a dart point and exhibits edge beveling created by pressure flaking (Figure $6 \mathrm{~b}$ ). The blade 
Table 1. Cultural materials recovered from 41HM46 by test unit

\begin{tabular}{|c|c|c|c|c|c|c|c|c|c|}
\hline \multirow[b]{2}{*}{ Test Unit } & \multirow{2}{*}{$\begin{array}{c}\text { Projectile } \\
\text { Points }\end{array}$} & \multirow{2}{*}{$\begin{array}{l}\text { Other } \\
\text { Lithic } \\
\text { Tools }\end{array}$} & \multirow[b]{2}{*}{ Cores } & \multirow[b]{2}{*}{ Debitage } & \multirow{2}{*}{$\begin{array}{c}\text { Mussel } \\
\text { Shells }\end{array}$} & \multicolumn{2}{|c|}{ Bones } & \multicolumn{2}{|c|}{ Burned Rocks } \\
\hline & & & & & & No. & Wt. (g) & No. & Wt. (kg) \\
\hline 1 & 0 & 0 & 0 & 30 & 49 & 80 & 28.8 & 89 & 2.6 \\
\hline 2 & 1 & 2 & 0 & 28 & 42 & 34 & 21.7 & 57 & 3.4 \\
\hline 3 & 0 & 0 & 1 & 19 & 39 & 23 & 13.4 & 18 & 0.7 \\
\hline 4 & 0 & 0 & 1 & 10 & 38 & 12 & 9.2 & 24 & 1.1 \\
\hline 5 & 0 & 2 & 0 & 21 & 47 & 58 & 35.0 & 43 & 1.4 \\
\hline 6 & 0 & 0 & 0 & 3 & 14 & 51 & 133.1 & 26 & 1.2 \\
\hline 7 & 0 & 2 & 0 & 3 & 16 & 6 & 7.6 & 29 & 1.0 \\
\hline Totals & 1 & 6 & 2 & 114 & 245 & 264 & 248.8 & 286 & 11.4 \\
\hline Items per $\mathrm{m}^{3}$ & 0.1 & 0.9 & 0.3 & 16.3 & 35.0 & 37.7 & 35.5 & 40.9 & 1.6 \\
\hline
\end{tabular}

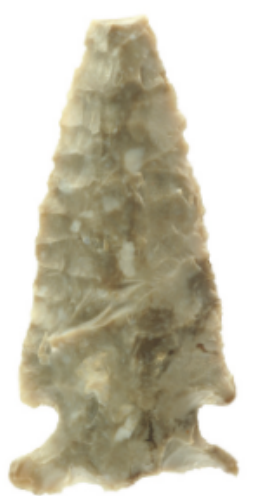

a
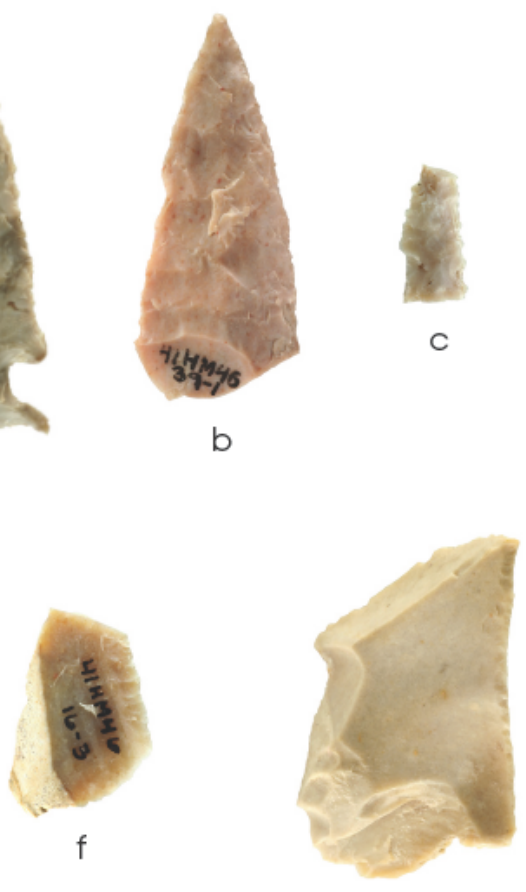

g

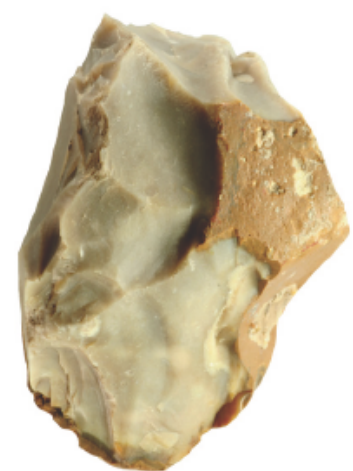

d

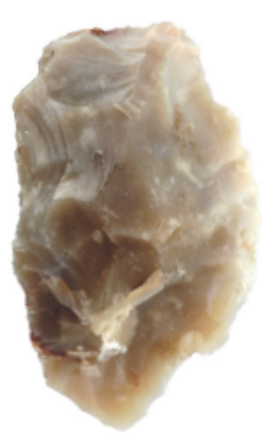

e

Figure 6. Lithic artifacts recovered from excavated contexts at 41HM46. (a) Ensor dart point; (b) distal fragment of dart point showing alternate beveling; (c) small dart or arrow point barb or tip; (d) small irregular biface made on chert pebble; (e) small early stage biface; (f-g) edge-modified flake fragments used as scraping tools.

fragment consists of a gray chert that had been heat treated prior to manufacture. A second biface fragment, from Test Unit 7, Level 9, is a ca. 15-mm long fragment of an arrow or dart point barb or tip (Figure 6c). The small size of this fragment precludes positive identification of type or form. Two other chert bifaces are crudely made and were recovered from Test Units 7 and 5, Level 5 (Figure 6d-e). The former was manufactured from a small rounded pebble and still retains about 40 percent of its original cortex. Although the edges exhibit some crushing, the function of this tool is not known. The latter is a small early-stage biface that was abandoned 
after several flake removals terminated in step or hinge fractures. Two edge-modified chert flake tools were recovered from Test Unit 2, Level 8, and both exhibit minor edge alteration along one edge and surface only (Figure $6 \mathrm{f}-\mathrm{g}$ ). The flaking along the edge of each piece appears to be the result of tool use in a scraping task and not the result of deliberate tool retouch.

Two cores were recovered from Test Unit 3, Level 8 and Test Unit 4, Level 7. The core from Test Unit 3 represents a small multidirectional core with remnant cortex on each end. The specimen from Test Unit 4 is the end of an elongate chert cobble that has been flaked as a core with a single platform. Both cores originated as small rounded to subrounded chert cobbles and were flaked with no specialized platform preparation. Their small size suggests that core reduction to produce flakes for tools was not a common activity, at least in the portion of the site tested.

\section{Unmodified Lithic Debitage}

The unmodified lithic debitage recovered from the site is a mixture of small and mediumsized cortical and non-cortical flakes. These flakes are comparable to flakes that would have been removed from the two cores described above or those removed from small to medium bifaces during tool resharpening and maintenance activities. The raw material is primarily chert. Test Unit 2, Level 8, was the only provenience to show a significant number of large flakes.

\section{Animal Bones and Freshwater Mussels}

The recovery of vertebrate faunal remains was fair, although the pieces typically were highly fragmented and not identifiable to the level of genus or species. Evidence for direct burning of bones was common. Many of the bones appear to be from smaller vertebrates, such as rabbits. The remains of a large mammal were found at the interface of the paleosol and the overlying alluvium in Test Units 6 and 7.

Mussel shells were incomplete, and often only the more robust umbos were recovered. The size of the mostly complete and fragmented specimens suggests that the average size of the mussel shells at 41HM46 was small, most not exceeding $3 \mathrm{~cm}$ in maximum length. Evidence of burning was observed on several shells.

\section{Macrobotanical Remains}

The recovery of macrobotanical remains was very low at the site. One unidentified carbonized seed was collected from the screen from Test Unit 2, Level 9. Flotation samples were taken from Test Unit 1, Levels 8-9, and Test Unit 5 , Levels $6-7$, to increase the probability of macrobotanical recovery. The entire southwestern quadrant of each unit/level was collected. These proveniences were chosen based on their horizontal separation from one another and on the overall high artifact frequency. These flotation samples yielded less than $0.4 \mathrm{~g}$ of wood charcoal. These remains, however, were not identified.

\section{Distribution of Artifacts and Other Materials}

Although artifact densities across the site were fairly low, an examination of the horizontal distribution of artifacts reveals some differences in frequencies (Table 2 and Figure 7). In Test Units 6 and 7 (in BHT 4 in the southwest corner of the known extent of the site) the number of chipped stone artifacts is very low $(n=8)$, whereas Test Units 1 and 2 (in BHT 5 in the northwestern part of the known extent of the site) yielded the greatest overall number of chipped stone artifacts $(\mathrm{n}=61)$. Test Units $3-5$ (located in BHT 3) yielded fewer chipped stone artifacts $(\mathrm{n}=54)$ than Test Units 1 and 2, but far more than Test Units 6 and 7. The distribution of mussel shells and burned rocks, by number and weight, reflects this pattern, but the distribution of vertebrate faunal remains is slightly different. By number of specimens, Test Units 1 and 2 yielded the greatest number of bones $(\mathrm{n}=114)$, but by total weight of specimens, Test Units 6 and 7 yielded the highest weight total $(140.7 \mathrm{~g})$. A highly fragmented large mammal bone found in Level 2 of Test Unit 6 largely accounts for this difference. Based on these numbers and distributions, it would appear that the northwestern and northern portions of the known site witnessed more activities, although with such a small area of the site examined, it is difficult to assess whether these distributions are truly meaningful.

The vertical distribution of artifacts and materials showed a somewhat variable pattern. Lithic artifacts peak in number in Level 8, with the second-highest number of chipped artifacts 


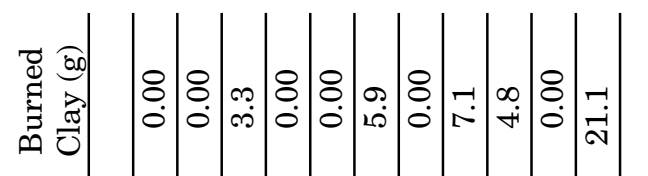
$\dot{0}=0$

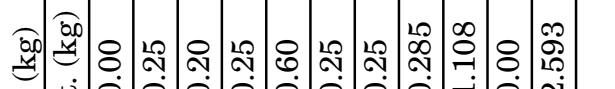

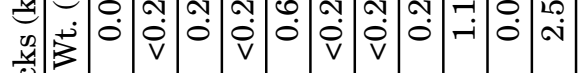

ำ

○े

๑

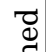

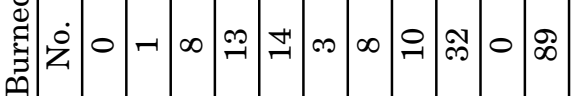

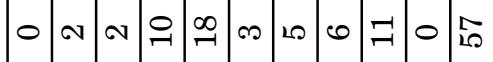

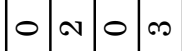

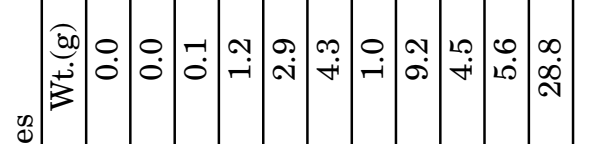

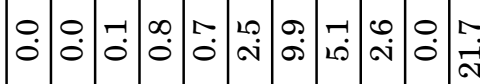

○.

Z

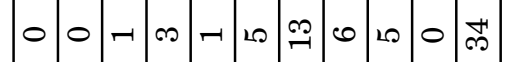

01000

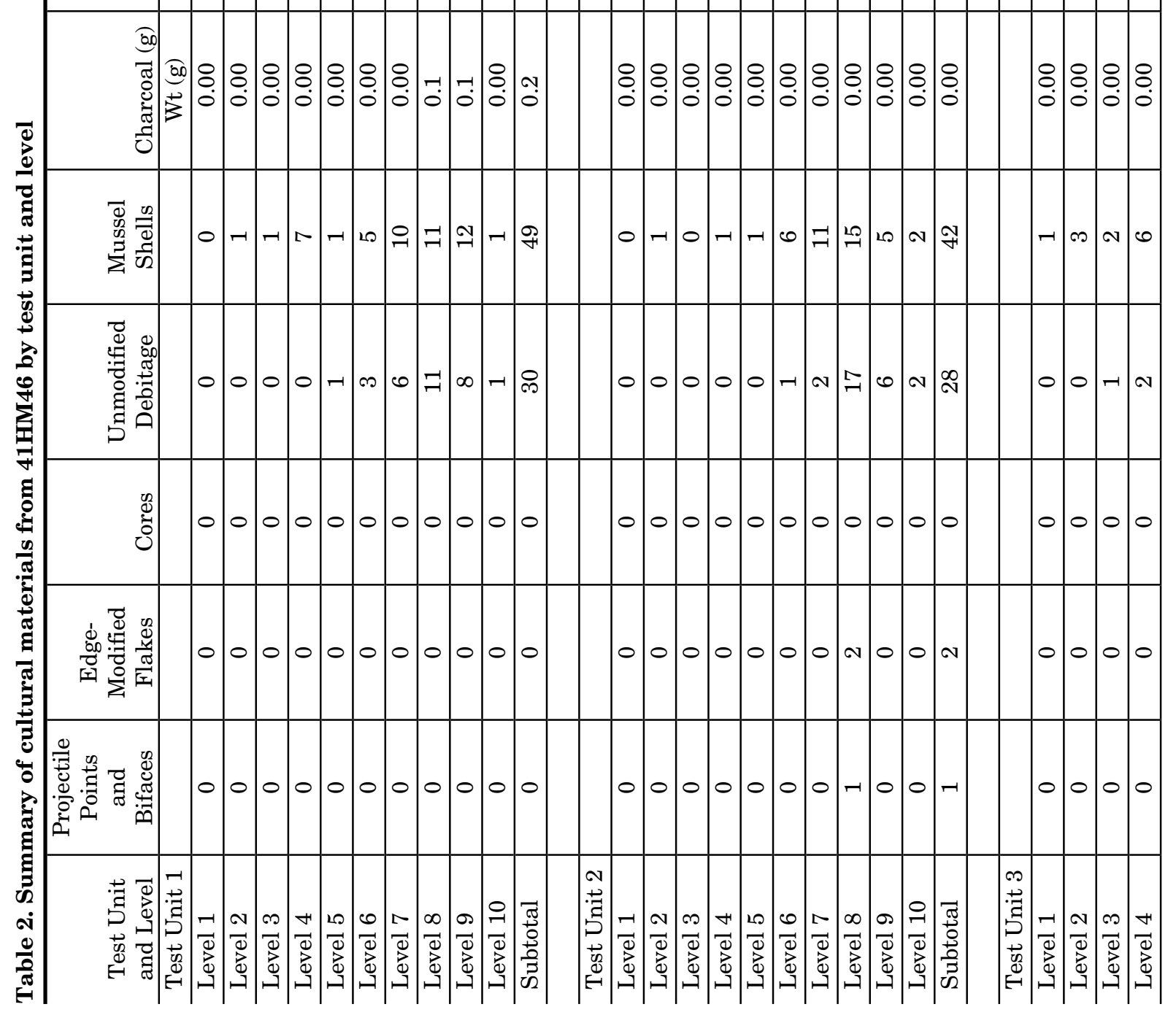




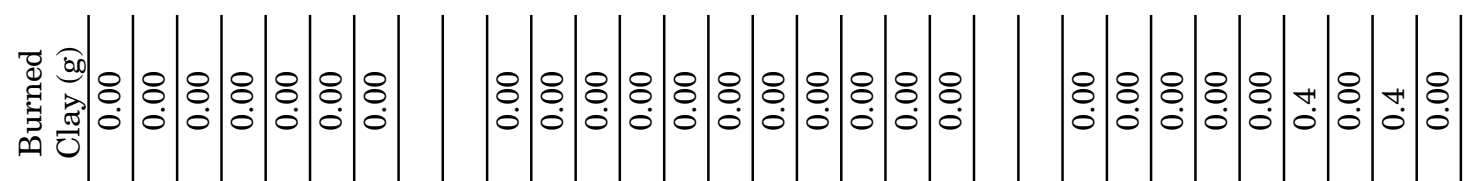

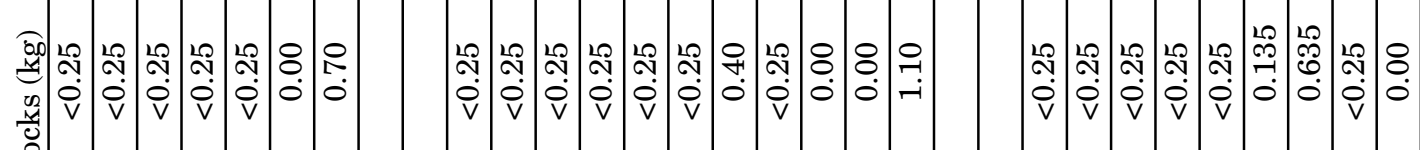

\%

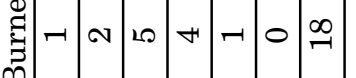

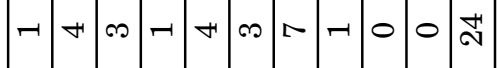

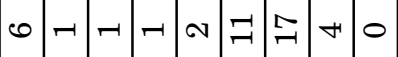



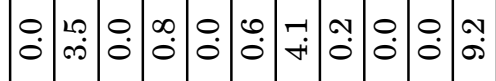

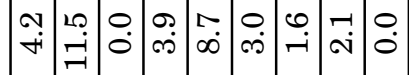

ڤุำ

ง ๓

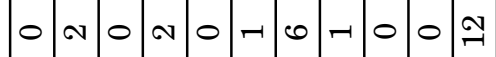

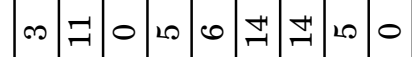

क्जم

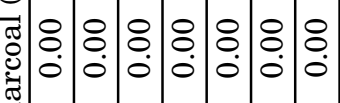

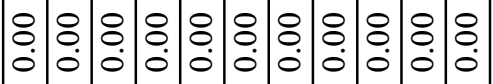

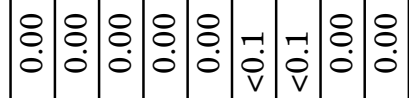

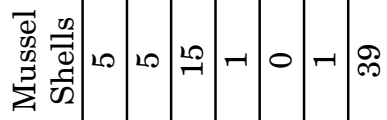

$\pi$ a $ง$ a 4 a

$\infty \pi \neg \infty$ m

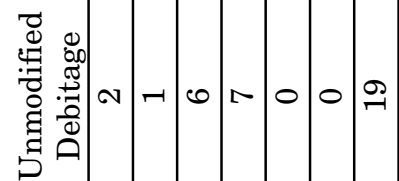

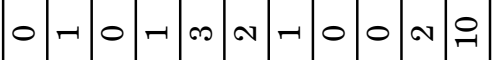

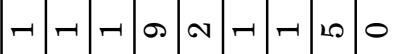

己.

$\begin{array}{llllllllllllll}0 & 0 & 0 & 0 & 0 & 0 & -1 & 0 & 0 & 0 & -1\end{array}$

000000000000

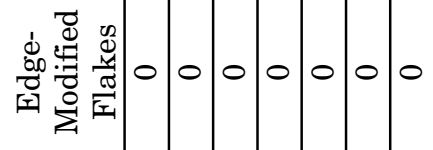

000000000000

00000000000

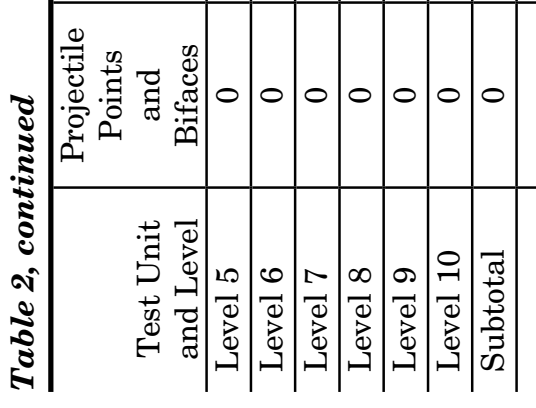

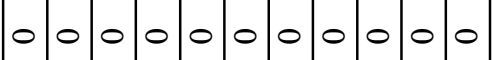

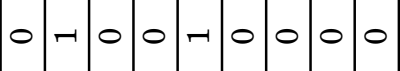

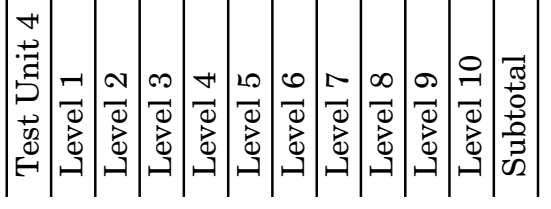

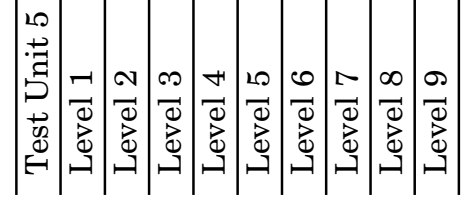




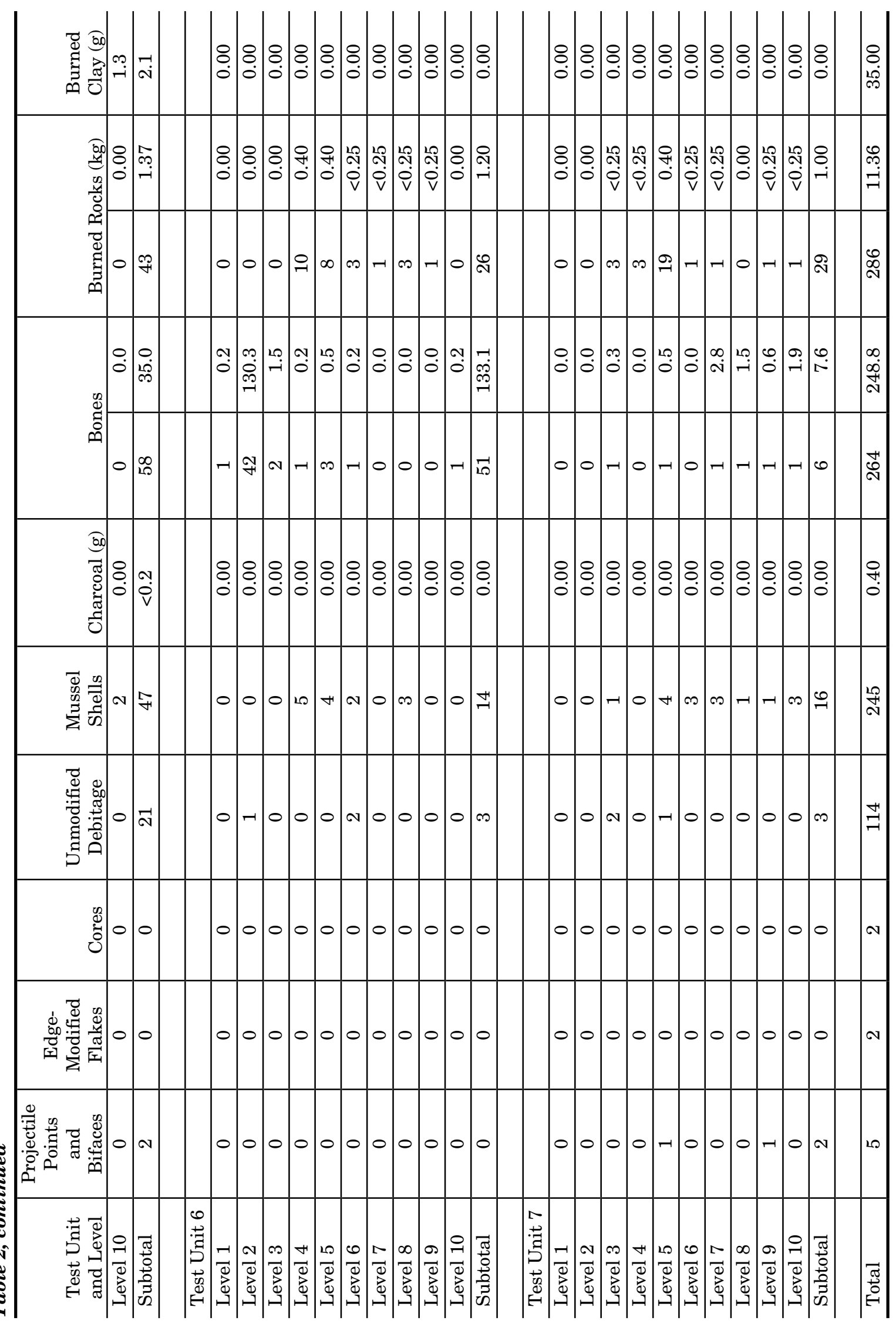



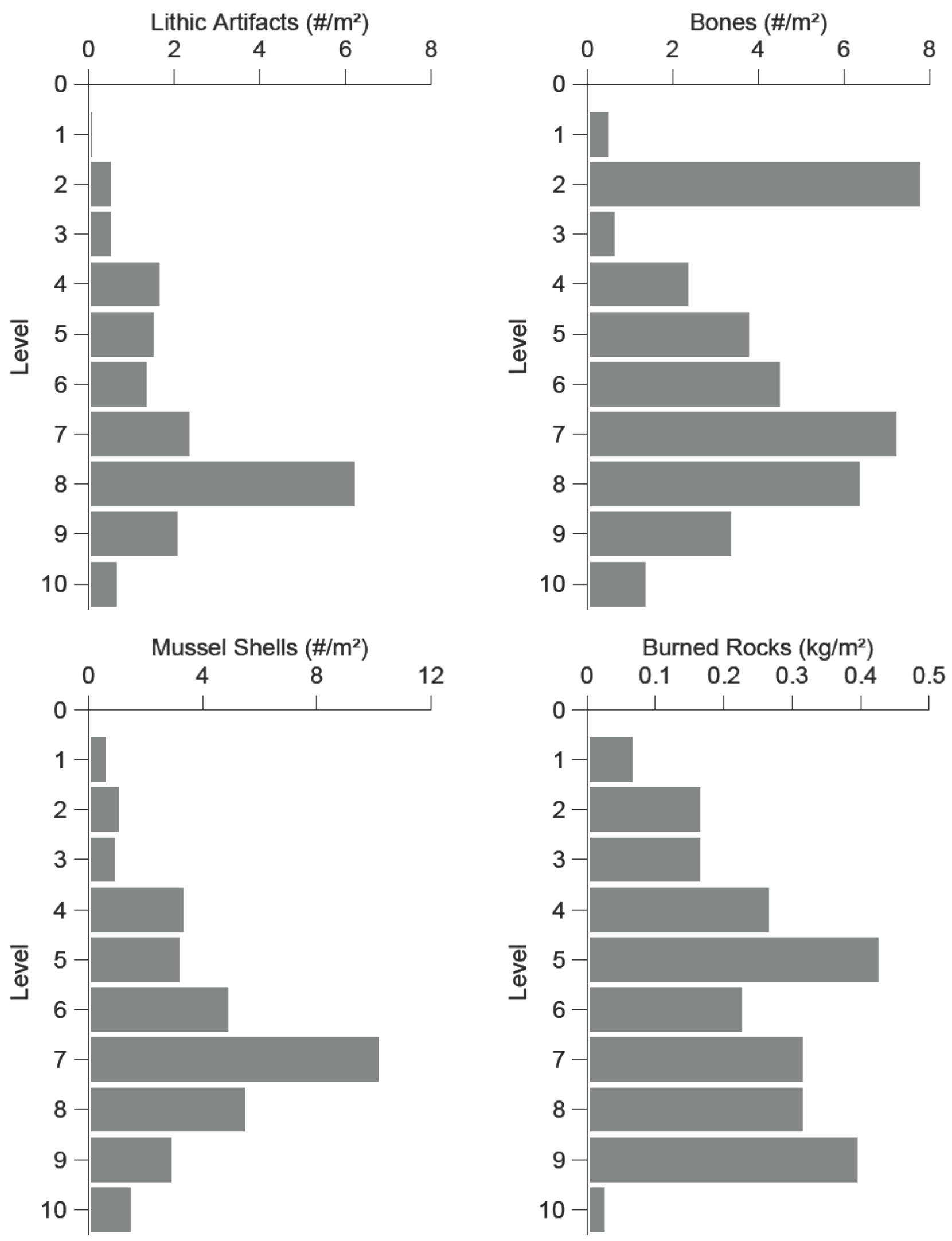

Figure 7. Graphs showing vertical distribution of cultural materials (number of specimens $/ \mathrm{m}^{2}$ ). 
occurring in Level 7. Level 7 also accounts for the highest number of mussel shells and the second highest number of bones. (The highest number of bones, in Level 2, is the result of one highly fragmented large mammal bone in Test Unit 6.) By weight, burned rocks peak in Level 5. Overall, the artifacts and other materials tend to increase in frequency with depth and peak throughout Levels 5-8 and dramatically decrease in number in Level 10. These artifact frequency peaks occur around the interface or boundary between the $2 \mathrm{Ab}$ and $2 \mathrm{Bb}$ soil horizons.

\section{Interpretative Summary}

The portion of 41HM46 within the project area is relatively intact and undisturbed. An examination of the horizontal distribution of artifacts and other cultural materials shows that items are more common along the northwestern edge of the known part of the site. Relatively significant quantities also are common in the northern area, while artifact recovery in the southwestern part of the site was much more limited. Cultural deposits from 50 to $80 \mathrm{cmbd}$ were most productive, with most of the artifacts and other cultural materials at the site coming from Levels 5-8 and significantly decreasing in number in Level 10. The overall artifact and cultural material recovery, however, was low.

The assemblage of artifacts, features, and other materials recovered at site 41HM46 suggests that the site is an open campsite that was occupied during the later part of the Late Archaic to possibly the Late Prehistoric. However, the assemblage is small and less than diverse, which hinders a broader understanding of the activities that took place at the site. The tool assemblage is small, with only one tool per cubic meter recovered from the excavations. The tool assemblage also lacks diversity, consisting only of one dart point, four bifaces, and two flake tools. The unmodified debitage assemblage is also small and provides few insights into raw material acquisition and tool production and maintenance. The two features are small, lack associated organic remains and artifacts, and are of a limited integrity, which prevents interpretations regarding function and age. Vertebrate faunal remains are few, highly fragmented, and only provide very limited insights into faunal resource utilization. Similarly, macrobotanical remains that might shed light on the local flora being exploited are largely lacking, despite flotation of several samples collected specifically for their recovery.

Also limiting the ability to address various research issues concerning Texas prehistory is the dearth of chronological data such as diagnostic tools or charcoal samples suitable for radiocarbon dating. Although an Ensor point was recovered from relatively artifact-dense levels, the span of time this deposit represents is unclear, as is the time span represented by the entire paleosol. Within the Leon River paleosol at site 41CV1482 on Fort Hood, an Ensor point was associated with a feature dated to $1880 \pm 70 \mathrm{~B}$. P. Additional radiocarbon ages from that site revealed a sequence of occupations within the paleosol ranging from $2140 \pm 70$ to $1060 \pm 60$ B.P. radiocarbon years. Charcoal radiocarbon ages from cultural features at three other sites within the paleosol at Fort Hood range up to $780 \pm 70$ B.P. (Austin phase), with most dates falling into the Austin phase (Mehalchick et al. 1999:119-145). Assuming a similar time span for the paleosol at 41HM46, a period of over one thousand years could be represented in the portion of the soil column between the Ensor point and the top of the paleosol. However, the dearth of temporally diagnostic artifacts and datable materials hinders confirmation of this.

Although the site assemblage is small and lacks chronological control, probably the most limiting factor is that artifacts and other materials cannot be isolated or separated into discrete temporal components despite the fact that the materials were recovered from a cumulic soil. Lacking this, it would be impossible to reconstruct the ranges of activities performed on the site during various occupation periods, nor is it realistic to consider the assemblage as a single analytical unit due to the overall small numbers of artifacts and materials found throughout the 1-m-thick cultural deposit.

\section{ASSESSMENT AND RECOMMENDATIONS}

Test excavations at 41HM46 consisted of three backhoe trenches, eight shovel tests, and seven hand-dug test units totaling $7 \mathrm{~m}^{3}$. Excavations yielded a small assemblage of chipped stone artifacts (tools, cores, and unmodified debitage), two features, and other cultural materials that appear to be associated with occupations 
ranging from the Late Archaic to possibly the Late Prehistoric. Although the artifacts and materials were primarily recovered from undisturbed contexts within a cumulic soil, there was no clear vertical separation of deposits or discrete components. This, along with the low artifact frequency, lack of well-defined features, and scarcity of potential temporal indicators such as diagnostic tools or charcoal for radiocarbon dating make the site unlikely to yield important information. Based on these factors, it is recommended that site 41HM46 be judged ineligible for listing in the National Register of Historic Places. 


\section{REFERENCES CITED}

Abbott, James T., and W. Nicholas Trierweiler (editors)

1995 NRHP Significance Testing of 57 Prehistoric Archeological Sites on Fort Hood, Texas, Volumes I and II. Archeological Resource Management Series, Research Report No. 34. United States Army, Fort Hood.

Baylor University 2007, 2008 \& 2009 Archaeological Field Schools

n.d. Retrieved from http://www.baylor.edu/content/services/document.php/110114.pdf. Accessed June 11, 2011.

Black, Stephen L., Linda W. Ellis, Darrell G. Creel, and Glenn T. Goode

1997 Hot Rock Cooking on the Greater Edwards Plateau: Four Burned Rock Midden Sites in West Central Texas, Volumes 1 and 2. Studies in Archeology 22. Texas Archeological Research Laboratory, The University of Texas at Austin, and Archeology Studies Program, Report 2. Environmental Affairs Division, Texas Department of Transportation, Austin.

Blair, Frank W.

1950 The Biotic Provinces of Texas. The Texas Journal of Science 2(1):93-117.

Broehm, Cory J., Karl W. Kibler, and E. Frances Gadus

2004 Interim Report on Survey and Test Excavations at 41HM46 and 41HM51, Hamilton County, Texas. Report submitted to Texas Department of Transportation, Environmental Affairs Division, Austin, Texas.

Brown, David O. (compiler)

1987 Archeology at Aquilla Lake, 1978-1982 Investigations, Volumes I-III. Research Report 81. Texas Archeological Survey, The University of Texas at Austin.

Bureau of Economic Geology

1976 The Geologic Atlas of Texas, Brownwood Sheet. Bureau of Economic Geology, The University of Texas at Austin.
Collins, Michael B.

1990 Observations on Clovis Lithic Technology. Current Research in the Pleistocene 7:73-74.

1995 Forty Years of Archeology in Central Texas. Bulletin of the Texas Archeological Society 66:361-400.

2004 Archeology in Central Texas. In The Prehistory of Texas, edited by Timothy K. Perttula, pp. 101-126. Texas A\&M University Press, College Station.

Collins, Michael B. (assembler)

1998 Wilson-Leonard:An 11,000-Year Archeological Record of Hunter-Gatherers in Central Texas, Volumes I-V. Studies in Archeology 31, Texas Archeological Research Laboratory, The University of Texas at Austin, and Archeology Studies Program, Report 10, Environmental Affairs Division, Texas Department of Transportation, Austin.

Collins, Michael B., and Bruce B. Bradley

2008 Evidence for Pre-Clovis Occupation at the Gault Site (41BL323), Central Texas. Current Research in the Pleistocene 25:70-72.

Collins, Michael B., Bruce Ellis, and Cathy DodtEllis

1990 Excavations at the Camp Pearl Wheat Site (41KR243): An Early Archaic Campsite on Town Creek, Kerr County, Texas. Studies in Archeology 6. Texas Archeological Research Laboratory, The University of Texas at Austin.

Collins, Michael B., Thomas R. Hester, and Pamela J. Headrick

1992 Engraved Cobbles from the Gault Site, Central Texas. Current Research in the Pleistocene 9:3-4.

Goode, Glenn T.

1991 Late Prehistoric Burned Rock Middens in Central Texas. In The Burned Rock Middens of Texas: An Archeological Symposium, edited by Thomas R. Hester, pp. 71-93. Studies in Archeology 13. Texas 
Archeological Research Laboratory, The University of Texas at Austin.

Goode, Glenn T., and Robert J. Mallouf

1991 The Evant Cores: Polyhedral Blade Cores from North-Central Texas. Current Research in the Pleistocene 8:67-70.

Griffith, Timothy B., Karl W. Kibler, and Douglas K. Boyd

2010 National Register Testing at 41BQ285, Bosque County, Texas: FM 56 Bridge Replacement at the North Bosque River. Reports of Investigations No. 160, Prewitt and Associates, Inc., Austin, and Archeological Studies Program, Report No. 101, Environmental Affairs Division, Texas Department of Transportation, Austin.

Hamilton-Coryell SWCD

n.d. Nontechnical Soils Description ReportHamilton County, Texas. Unpublished manuscript of the Hamilton-Coryell Soil and Water Conservation District, Hamilton, Texas.

Hatfield, Virginia L.

1997 Paleoindian Evidence at the Triple S Ranch Site, Hamilton County, Texas. Current Research in the Pleistocene 14:32-34.

Hays, Thomas R., and Foster E. Kirby

1977 Hog Creek Testing Project: Preliminary Results. Report submitted to the U.S. Department of Agriculture, Soil Conservation Service, Temple, Texas.

Hayward, O. T., Peter M. Allen, and David L. Amsbury

1996 Lampasas Cut Plain: Episodic Development of an Ancient and Complex Regional Landscape, Central Texas. In Guidebook to Upland, Lowland, and In Between: Landscapes in the Lampasas Cut Plain, edited by David L. Carlson, pp. 1-1 to 1-97. Friends of Pleistocene South-Central Cell 1996 Field Trip. Department of Anthropology, Texas A\&M University, College Station, and Department of Geology, Baylor University, Waco, Texas.

Henry, Donald O.

1995 Cultural and Paleoenvironmental Successions Revealed by the Hog Creek Archeological Investigation, central Texas. In Advances in Texas Archeology: Contributions from Cultural Resources Management, edited by James E. Bruseth and Timothy K. Perttula pp. 51-79. Cultural
Resource Management Report 5. Division of Antiquities Protection, Texas Historical Commission, Austin.

Henry, Donald O., Foster E. Kirby, and Anne B. Justen

1980 The Prehistory of Hog Creek: An Archaeological Investigation of Bosque and Coryell Counties, Texas. Laboratory of Archaeology, Department of Anthropology, University of Tulsa, Oklahoma.

Huebner, Jeffery A.

1991 Late Prehistoric Bison Populations in Central and South Texas. Plains Anthropologist 36(137):343-358.

Jelks, Edward B.

1953 Excavations at Blum Rockshelter. Bulletin of the Texas Archeological and Paleontological Society 24:189-207.

1962 The Kyle Site: A Stratified Central Texas Aspect Site in Hill County, Texas. Archeology Series No. 5. Department of Anthropology, The University of Texas at Austin.

Johnson, LeRoy, and Glenn T. Goode

1994 A New Try at Dating and Characterizing Holocene Climates, as well as Archeological Periods, on the Eastern Edwards Plateau. Bulletin of the Texas Archeological Society 65:1-51.

Kibler, Karl W.

2003 Archeological Survey on CR 294 at the Leon River, Hamilton County, Texas. Letter Report No. 607, Prewitt and Associates, Inc., Austin, Texas.

Kibler, Karl W., and Cory J. Broehm

2005 Data Recovery at Site 41HM51, Hamilton County, Texas. Current Archeology in Texas 7(1):18-22.

Kibler, Karl W., and Gemma Mehalchick

2010 Hunter-Gatherer Resource Acquisition and Use in the Lower Bosque River Basin During the Late Archaic. Bulletin of the Texas Archeological Society 81:103-126.

Kleinbach, Karl, Gemma Mehalchick, James T. Abbott, and J. Michael Quigg

1995 Other Analyses. In NRHP Significance Testing of 57 Prehistoric Archeological Sites on Fort Hood, Texas, Volume II, edited by James T. Abbott and Nicholas Trierweiler, pp. 765-842. Archeological Resource Management Series, Research 
Report No. 34. United States Army, Fort Hood.

Kleinbach, Karl, Gemma Mehalchick, Douglas K. Boyd, and Karl W. Kibler

1999 National Register Testing of 42 Prehis toric Archeological Sites on Fort Hood Texas: The 1996 Season. Archeological Resource Management Series, Research Report No. 38. United States Army, Fort Hood.

Kvernes, Kimberly K., Marie E. Blake, Karl W. Kibler, Jennifer K. McWilliams, E. Frances Gadus, and Ross C. Fields

2000 Relocation and Updated Recordation of 44 Archeological Sites at Waco Lake, McLennan County, Texas. Reports of Investigations No. 127. Prewitt and Associates, Inc., Austin.

Larson, Richard E., and Foster E. Kirby

1976 Test Excavations at the L.E. Robertson Shelter and the Stone Rockshelter, Coryell County, Texas. Research Report 87, Archeology Research Program. Southern Methodist University, Dallas, Texas.

Larson, Richard E., Duane E. Peter, Foster E. Kirby, and S. Alan Skinner

1975 An Evaluation of the Cultural Resources at Hog Creek. Research Report 84. Archeology Research Program, Southern Methodist University, Dallas, Texas.

Lynott, Mark J., and Duane E. Peter

1977 Archeological Investigations at Aquilla Lake, 1975. Research Report 102. Archeology Research Program, Southern Methodist University, Dallas, Texas.

McKinney, Wilson W.

1981 Early Holocene Adaptations in Central and Southwestern Texas: The Problem of the Paleoindian-Archaic Transition. Bulletin of the Texas Archeology Society 52:91-120.

Mehalchick, Gemma, Douglas K. Boyd, Karl W. Kibler, and Christopher W. Ringstaff

2004 Shifting Sands and Geophytes: Geoarcheological Investigations at Paluxy Sites on Fort Hood, Texas. Archeological Resource Management Series, Research Report No. 48. United States Army, Fort Hood.

Mehalchick, Gemma, and Karl W. Kibler 2008 Hunters and Gatherers of the North Bosque River Valley: Excavations at the Baylor,
Britton, McMillan, and Higginbotham Sites, Waco Lake, McLennan County, Texas. Reports of Investigations No. 156. Prewitt and Associates, Inc., Austin, Texas.

Mehalchick, Gemma, Karl Kleinbach, Douglas K. Boyd and Karl W. Kibler

2000 Geoarcheological Investigations and National Register Testing of 52 Prehis toric Archeological Sites on Fort Hood, Texas: The 1997 Season. Archeological Resource Management Series, Research Report No. 39. United States Army, Fort Hood.

Mehalchick, Gemma, Karl Kleinbach, Douglas K. Boyd, Steve A. Tomka, and Karl Kibler

1999 National Register Testing of 19 Prehistoric Archeological Sites at Fort Hood, Texas: The 1995 Season. Archeological Resource Management Series, Research Report No. 37. United States Army, Fort Hood.

Miller, E. O., and Edward B. Jelks

1952 Archeological Excavations at the Belton Reservoir, Coryell County, Texas. Bulletin of the Texas Archeological and Paleontological Society 23:168-217.

Moore, Joe D., Billy W. Kendrick, Billy J. Wagner, and Edward R. Harris

1977 Soil Survey of Comanche County, Texas. U.S. Department of Agriculture, Soil Conservation Service, in cooperation with the Texas Agricultural Experiment Station.

Nordt, Lee C.

1992 Archaeological Geology of the Fort Hood Military Reservation, Fort Hood, Texas. Archaeological Resource Management Series, Research Report No. 25. United States Army, Fort Hood.

Prewitt, Elton R.

1981 Cultural Chronology in Central Texas. Bulletin of the Texas Archeological Society 52:65-89.

1985 From Circleville to Toyah: Comments on Central Texas Chronology. Bulletin of the Texas Archeological Society 54:201-238.

Redder, Albert J.

1985 Horn Shelter Number 2: The South End, A Preliminary Report. Central Texas Archeologist 10:37-65.

Shafer, Harry J.

1963 Test Excavations at the Youngsport Site: 
A Stratified Terrace Site in Bell County, Texas. Bulletin of the Texas Archeological Society 34:57-81.

1977 Late Prehistory of Central Texas. Bulletin of the South Plains Archeological Society $3: 18-24$.

2006 People of the Prairie: A Possible Connection to the Davis Site Caddo. Report prepared for the Archeological Studies Program, Environmental Affairs Division, Texas Department of Transportation, Austin. Electronic document, http:// www.counciloftexasarcheologists.org/ publications/PrairieCaddoModule.pdf, accessed November 8, 2011.

Shafer, Harry J., Dee Ann Suhm, and J. Dan Scurlock

1964 An Investigation and Appraisal of the Archeological Resources of Belton Reservoir, Bell and Coryell Counties, Texas: 1962. Miscellaneous Papers No. 1. Texas Archeological Salvage Project, The University of Texas at Austin.

Skinner, S. Alan, and Mark L. Henderson

1972 Archeological Resources of the Aquilla Lake Watershed. In The Natural and Cultural Environmental Resources of Aquilla Lake Watershed, Hill County, Texas, assembled by S. Alan Skinner, pp. 30-62. Institute for the Study of Earth and Man, Southern Methodist University, Dallas, Texas.

Skinner, S. Alan, C. Shaw, K. Huckaby, and M. L. Bartsch

1978 An Evaluation of Archaeological Research at Aquilla Lake. Archaeology Research Program, Southern Methodist University, Dallas, Texas.

Sorrow, William M., Harry J. Shafer, and Richard E. Ross

1967 Excavations at Stillhouse Hollow Reservoir. Miscellaneous Papers No. 11. Texas Archeological Salvage Project, The University of Texas at Austin.

Stephenson, Robert L.

1947 Archeological Survey of Whitney Basin: A Preliminary Report. Bulletin of the Texas Archeological and Paleontological Society 18:129-142.
1970 Archeological Investigations in the Whitney Reservoir Area, Central Texas. Bulletin of the Texas Archeological Society 41:37-377.

Story, Dee Ann

1985 Adaptive Strategies of Archaic Cultures of the West Gulf Coastal Plain. In Prehistoric Food Production in North America, edited by Richard I. Ford, pp. 19-56. Anthropological Papers No. 75. Museum of Anthropology, University of Michigan, Ann Arbor.

1990 Cultural History of the Native Americans. In The Archeology and Bioarcheology of the Gulf Coastal Plain, by Dee Ann Story, Janice A. Guy, Barbara A. Burnett, Martha Doty Freeman, Jerome C. Rose, D. Gentry Steele, Ben W. Olive, and Karl J. Reinhard, pp. 163-366. Research Series No. 38. Arkansas Archeological Survey, Fayetteville.

Story, Dee Ann, and Harry J. Shafer

19651964 Excavations at Waco Reservoir, McLennan County, Texas: The Baylor and Britton Sites. Miscellaneous Papers No. 6. Texas Archeological Salvage Project, The University of Texas at Austin.

Suhm, Dee Ann

1960 A Review of Central Texas Archeology. Bulletin of the Texas Archeological Society 29:63-107.

Toomey, Rickard S., III, Michael D. Blum, and Salvatore Valastro Jr.

1993 Late Quaternary Climates and Environments of the Edwards Plateau, Texas. Global and Planetary Change 7:299-320.

Trierweiler, W. Nicholas (editor)

1994 Archeological Investigations on 571 Sites at Fort Hood, Bell and Coryell Counties, Texas. Archeological Resource Management Series, Report No. 31. United States Army, Fort Hood.

1996 Archeological Testing at Fort Hood, 1994-1995, Volumes I and II. Archeological Resource Management Series, Report No. 35. United States Army, Fort Hood.

Turner, Ellen Sue, and Thomas R. Hester

1993 A Field Guide to Stone Artifacts of Texas Indians. Second Edition. Gulf Publishing Company, Houston, Texas. 
Waters, Michael R., Steven L. Forman, Thomas A. Jennings, Lee C. Nordt, Steven G. Driese, Joshua M. Feinberg, Joshua L. L. Keene, Jessi Halligan, Anna Lindquist, James Pierson, Charles T. Hallmark, Michael B. Collins, and James E. Wiederhold

2011 The Buttermilk Creek Complex and the Origins of Clovis at the Debra L. Friedkin Site, Texas. Science 331:1599-1603.

Watt, Frank H.

1953 Pottery Diffusions of the Central Brazos Valley. Central Texas Archeologist 6:5785.

1956 Archeological Materials from the Asa Warner Site. Central Texas Archeologist 7:7-29.
1978 Radiocarbon Chronology of Sites in the Central Brazos Valley. Bulletin of the Texas Archeological Society 49:111-138.

Weir, Frank A

1976 The Central Texas Archaic. Ph.D. dissertation, Department of Anthropology, Washington State University, Pullman.

Willey, Gordon R., and Philip Phillips

1958 Method and Theory in American Archaeology. University of Chicago Press, Chicago.

Wright, Jodi F.

1997 The Asa Warner Site (41ML46), McLennan County, Texas. Bulletin of the Texas Archeological Society 68:215-261. 